\title{
Mineralogy and Petrology \\ Melting, fluid migration and fluid-rock interactions in the lower crust beneath the Bakony-Balaton Highland Volcanic Field: a silicate melt and fluid inclusion study --Manuscript Draft--
}

Manuscript Number:

Full Title:

Article Type:

Keywords:

Corresponding Author:
MIPE-D-14-00029R1

Melting, fluid migration and fluid-rock interactions in the lower crust beneath the Bakony-Balaton Highland Volcanic Field: a silicate melt and fluid inclusion study

\section{Standard Article}

granulite xenolith, partial melting, silicate melt and fluid inclusions, IR analyses, Pannonian Basin

Bianka Julianna Németh

Geological and Geophysical Institute of Hungary

Budapest, HUNGARY

\section{Corresponding Author Secondary}

Information:

Corresponding Author's Institution:

Geological and Geophysical Institute of Hungary

\section{Corresponding Author's Secondary} Institution:

First Author: Bianka Julianna Németh

First Author Secondary Information:

Order of Authors:

Bianka Julianna Németh

Kálmán Török

István Kovács

Csaba Szabó

Rainer Abart

Júlia Dégi

Judit Mihály

Csaba Németh

Order of Authors Secondary Information:

Abstract:

Plio-Pleistocene alkali basalt hosted mafic garnet granulite xenoliths were studied from the Bakony-Balaton Highland Volcanic Field (BBHVF) to trace fluid-melt-rock interactions in the lower crust. Two unique mafic garnet granulite samples were selected for analyses (optical microscopy, microthermometry, electron microprobe, Raman and IR spectroscopy), which contain clinopyroxene-plagioclase vein and patches with primary silicate melt inclusions (SMI). The samples have non-equilibrium microtexture in contrast with overwhelming majority of previously studied mafic garnet granulite xenoliths. Primary silicate-melt inclusions were observed in plagioclase, clinopyroxene and ilmenite in both xenoliths. The SMI-bearing minerals located randomly in Mi26 and in a clinopyroxene-plagioclase vein on the edge of Sab38 granulites. Petrography, fluid and melt inclusion study suggests that at least three fluid events occurred in the deep crust represented by these xenoliths.

1. Primary $\mathrm{CO} 2$-dominated $\pm \mathrm{CO} \pm \mathrm{H} 2 \mathrm{~S}$ fluid inclusions were observed in the wall-rock part of Sab38 xenolith

2. The crystallization of new clinopyroxene from melt, with $\mathrm{CO} 2+\mathrm{H} 2 \mathrm{O}$ fluid.

3. The crystallization of new plagioclase occurred in a heterogeneous fluid-melt system with additional $\mathrm{N} 2$ and $\mathrm{CH} 4$ during crystallization. A local reaction was observed between sphene and acidic melt, which formed ilmenite+clinopyroxene+plagioclase \pm orthopyroxene.

The 'water' content of the rock forming minerals was determined by infrared spectroscopy. The calculated bulk 'water' content of the Mi26 xenolith is $171 \pm 51 \mathrm{ppm}$ 
wt. \%. The bulk wall rock part of the Sab38 granulite contains $55 \pm 17$ ppm wt. \% of 'water', whereas the bulk plagioclase-clinopyroxene vein contains $278 \pm 83$ ppm wt. \%. These results imply a very dry lower crust, locally hydrated by percolating fluids and melts.

\section{Response to Reviewers:}

Replies to the comments of the Reviewer \#1 and to the general comments of Reviewer \#2.

Reviewer \#1:

Page 2 Line 49: thinner or thicker?

We corrected the word in question.

Page 3 Line 18: Please describe the precision and accuracy of the energy-dispersive method.

We clarified the asked method in the 'Analytical technique' section.

Page 3 Line 46: "atmpspheric" should be "atmospheric".

We corrected the word in question.

Page 4 Line 6: Please delete the word "selected" or "studied".

We deleted the unnecessary word.

Page 6 line 7: Please describe how you estimate the errors of P-T.

Sources of error considered include: accuracy of the experimentally located, barometric end-member reaction, volume measurement errors, analytical imprecision, uncertainty of electron microprobe standard compositions, thermometer calibration errors, variation in the different mineral assemblage activity models, and compositional heterogeneity of natural minerals (Kohn and Spear, 1991). We clarified the asked method in the 'Geothermo-barometry' section.

Page 6 Line 50: "isochor" should be "isochore".

We corrected the world in question.

Page 7 Line 30: 189 ppm and 193 ppm have no difference when error is considered. Yes this is true, our intention was just to give the range of water content in orthopyroxene similarly to the other minerals.

Reviewer \#2: This manuscript describes the analyses of melt and fluid inclusions in xenolites in basalts, in addition to "bulk water" analyses of minerals to illustrate that these xenolties originated in a „dry" lower crust environment. The analytical techniques of fluid and melt inclusions are not sufficient for the presented discussion and conclusions. If table 3 represents the number of inclusions measured ( 5 fluid inclusions and 4 melt inclusions), then it must be concluded that the lack of data in this manuscript does not justify a publication. You cannot discuss or model processes in the lower crust based the analyses of only a few inclusions.

It might have escaped the attention of the referee that we marked the number of the successful measurements made on fluid inclusions and bubbles of melt inclusions in the last column of Table 3. We report Raman analyses made on 35 inclusions (and bubbles) ( $8 \mathrm{FI}$ and $27 \mathrm{SMI}$ ), not only $5 \mathrm{FI}$ and $4 \mathrm{SMI}$ as it is stated by the referee. It is true, that we could not measure the bubbles of melt inclusions and the fluid inclusions with microthermometry, due to their small size and dark appearance. We made discussion of inclusion contents based on the Raman analyses of 35 successfully measured inclusions (Table 3), which allowed us to characterize the composition of the different generations properly. Furthermore we made 89 IR point analyses on minerals in different textural positions (see Table 4), and 12 IR profiles across clinopyroxene and plagioclase grains with 111 point analyses altogether to characterize the water content of the minerals and the distribution of the water in the minerals (We wrote the latter number in the capture of the Fig.4, but all the numbers of measurements were indicated in Table 3 and 4). Furthermore the IR analyses helped us to prove that the type $\mathrm{V}$ silicate melt inclusions contained appreciable amounts of water. In the light of these data we feel the criticism of the referee too harsh and unfounded.

To avoid further similar conclusions from readers we put our IR data in two electronic supplementary files. 
The description of the xenolites includes a lot of fluid-rock interactions, but the authors decide for a "very dry lower crust" in their conclusions.

Yes, we decided for a very dry lower crust on the basis of IR data of the garnet granulite part of the rock, which was invaded by a melt which caused fluid-rock interaction. Some new clinopyroxene and plagioclase bearing veins and pods were formed as a result of fluid-rock interaction. The new minerals contained silicate melt inclusions and the water content of the new mineral assemblage was higher than that of the garnet granulite. Let us quote here the final sentences of our discussion: "Using the average modal compositions (Chapter 4.1), the total structurally bound 'water' content of the SMI-bearing clinopyroxene-plagioclase rich parts of the Mi26 xenolith is $413 \pm 124 \mathrm{ppm}$ wt. \% which is much higher than that of the garnet-bearing SMI-free parts $(77 \pm 23 \mathrm{ppm}$ wt. \%). Also in Sab38 the plagioclase-clinopyroxene vein of the sample contains higher amounts of 'water' ( $390 \pm 117 \mathrm{ppm}$ wt. \%), than the wall-rock part (55 $\pm 17 \mathrm{ppm}$ wt. \%). This implies, that the originally dry garnet bearing mafic granulite was partially 'hydrated' by fluid-rich melts during fluid-rock interactions."

Thus we concluded, that the fluid-rock interaction caused partial rehydration of the originally dry rock. This is the story we suggested on the basis of petrography, mineral chemistry, Raman and IR analyses, but it seems that the story as well as the data supporting it might have escaped the attention of the referee.

This manuscript needs improvements in English in some parts (as illustrated in the specific comments). In its present form, this manuscript cannot be accepted for publication.

Reply to the comments of Reviewer\#2 on the manuscript.

Manuscript number: MIPE-D-14-00029

Title:Melting, fluid migration and fluid-rock interactions in the lower crust beneath the Bakony-Balaton Highland Volcanic Field: a silicate melt and fluid inclusion study Authors: Németh et al.

Specific comments

Line $57-61$ (page 1) and line 1-2 (page 2): this paragraph can be included in the previous paragraph because most of the information given is already presented in the previous paragraph:

We included the above mentioned paragraph in the previous one and deleted the unneccessary sentences.

Line 4 (page 2): in the previous paragraph you describe that "several generation of fluid inclusion" and "fluid/melt rock interactions" were already described by Degi and Torok, but here you mention that there is "no direct evidence" of the presence of melt. If these older studies only suggested the presence of a melt (but not observed) then it must be presented as such.

We rephrased the criticized sentence.

Line 8 (page 2): it is very unlikely that you have studied several hundreds of thin sections, and only present here so little.

Even if it seems to be unlikely for the reviewer, we studied more than 400 thin sections made of the lower crustal xenoliths from 6 localities (Mindszentkálla, Szentbékkálla, Káptalantóti, Szigliget, Kapolcs and Tihany) and unfortunately only these two ones contained primary SMI in the rock forming minerals. This is the reason why we present 'so little'.

Line 28 (page 2): you should mention in the text what is the meaning of nd . The is the crustal thinning factor, which is defined as the ratio of initial crustal thickness divided by the final crustal thickness. The is the same for the mantle lithosphere. We rephrased the text to be more straightforward.

Line 35 --- 39 (page 2): first you mention that the second stage was "followed" by volcanism, and later you mention "coeval". This is inconsistent. We clarified the sentence.

Line $53-57$ (page 2): the description of the xenolites is not complete, because later in 
the discussion you mention the presence of veins within the xenolites. Furthermore, because you also describe the rock around the xenolites, you must also give information about this rock (at least in the paragraph "petrography").

In the lines in question we give a general description of the mafic garnet granulite xenoliths found in the localities of the Bakony - Balaton Highland as a part of the geological description. These xenoliths do not contain veins. The detailed description of the studied xenoliths, one with a clinopyroxene-plagioclase vein (Sab38 xenolith) belongs to the 'Petrography' section. The description of the vein in question can be found there.

We wrote in the 'Introduction' section that the xenoliths are included in Plio-Pleistocene alkaline basalt and basaltic tuff. We also give some relevant papers in the 'Introduction' and 'Geology' sections, which are dealing with the alkaline basalts in details for interested readers. This is the conventional way of referring to the host rock in papers dealing with xenoliths. The aim of this paper is to report fluid-melt-rock interactions observed in xenoliths that is why we did not deal with the basalts.

Line 3 ---5 (page 3): You describe the infiltration of a CO2---rich fluid: how does this produce a melt, or the formation of "metasomatic mineral assemblage" (per definition without a melt).

We changed the metasomatic assemblage to 'new' mineral assemblage, although in the conventional terminology of the lower lithospheric processes (lower crust and upper mantle) we usually do not make distinction between metasomatism caused by fluids and/or melt.

Several experimental and field studies describe how does a $\mathrm{CO} 2$ rich (The $\mathrm{CO} 2$-rich means a fluid which is not $100 \%$ CO2! It may contain other components, like water etc. See e.g. later in this paper) fluid induce partial melting and/or produce new mineral assemblages.

We provide here some experimental basis on the effect of $\mathrm{CO} 2$-rich fluids on partial melting of high grade metamorphic rocks:

Peterson JW Newton RC (1990) Experimental biotite-quartz melting in the KMASH$\mathrm{CO} 2$ system and the role of $\mathrm{CO} 2$ in the petrogenesis of granites and related rocks. Am Mineral 75:1029-1042

Kaszuba, JP. , Wendlandt, R.F. (2000) Effect of Carbon Dioxide on Dehydration Melting Reactions and Melt Compositions in the Lower Crust and the Origin of Alkaline Rocks. Journal of Petrology, Vol. 41. 363-386

Line 10 - 11 (page 3): you must explain the "9---20 hours" process.

We give the refence of Dégi et al., (2009), where the authors describe how they reached this conclusion using diffusion modelling of ilmenite with exsolved titanomagnetite.

Line 34 - 37 (page 3): How do you use a Linkam stage to determine the $\mathrm{H} 2 \mathrm{O}$ content with microthermometry in a fluid inclusion?

Actually the Linkam stage was used just to heat the fluid inclusions up to $150^{\circ} \mathrm{C}$. We made the Raman spectroscopy in heated fluid. We clarified the relevant sentence. You do not present any data of microthermometry (except one $\mathrm{H} 2 \mathrm{O}---$ free melt inclusion). Yes because the inclusions were too dark to see any phase transition under microscope. See 'Microthermometry and Raman analyses on fluid and silicate melt inclusions' section. Actually we presented microthermometry data from 2 inclusions. Although we admit that it is not too much, but we used the Raman data to interpret the compositions of the different generations of gas bubbles and fluid inclusions instead. The Raman method described by Berkesi is based on the analyses above total homogenization temperatures (when a homogeneous fluid is present). The illustrated temperature range of 100 to $200{ }^{\circ} \mathrm{C}$ is irrelevant, because total homogenization may often occur at different temperatures. Moreover, $\mathrm{H} 2 \mathrm{O}$ is better detectable in the rim of inclusions if it is present as a liquid phase at room temperatures.

We made Raman analyses to determine the composition of the gas bubbles and fluid inclusions. Our specific goal was the determination of water. To reach this goal we made Raman analyses at room temperature and at $150 \mathrm{oC}$, following the method of Berkesi et al (2009), which is a tested and working method (Berkesi et al., 2009, Fig. 1., Table 1) successfully applied in Raman laboratory, where we made our measurements and in other labs as well. It is easier and more effective, than finding a thin water film at the edge of the bubbles, where a big part of the laser hits either the host and scattered from the curved surface of the inclusions resulting in poorer peak 
intensities. This makes it difficult to detect the components with low concentration, like the water in our case.

Finding a small piece of clathrate in a frozen inclusion is not an easy way to detect the presence of small amounts of water in a water-bearing $\mathrm{CO} 2$ inclusion. This is much more time consuming method, than the one we applied.

The advantages and disadvantages of the applied method are also summarized in Berkesi et al. (2009; Table 1.). The main advantage of using Raman analyses in the interval of $100-200^{\circ} \mathrm{C}$, is that $\mathrm{CO} 2$ and $\mathrm{H} 2 \mathrm{O}$ are homogeneously distributed in the inclusion. Thus the location of the laser spot within the fluid inclusion is not critical compared with finding a thin film or a small solid clathrate. The main disadvantage of this method is the moderate risk of decrepitation during heating.

Missing in analytical methods: 1. You have given in table 3 the gas composition of the vapour phase in fluid and melt inclusions. You do not give information how you have obtained these calculated values. Indeed, I compensated it: Even though the complete homogenization of the fluid inclusion cannot be recognized, at high temperature the distribution of dissolved $\mathrm{H} 2 \mathrm{O}$ in $\mathrm{CO} 2$ is presumably uniform, which allows (semi-) quantification of spectra of the CO2-rich phase according to the method of J. Dubessy, M. C. Boiron, A. Moissette, C. Monnin, N. Sretenskaya, Determination of water, hydrates and pH in fluid inclusions by micro-Raman spectrometry. Eur. JMineral. 1992, 4, 885-894.

2. Calculation of isochores with equations of state is done with the software ISOC, there is a reference for this: Bakker (2003). The method of calculations should be given in analytical methods.

3. The calculation method to obtain the density of $\mathrm{CO} 2$ from Raman spectra must be described in the analytical methods (and not in line 43 ---48, page 6). The method of Fall is not valid (see Bakker, 2011, ECROFI XXI, Berichte der Geologische

Bundesanstalt, vol. 87, p. 32---33), and cannot be used to determine the $\mathrm{CO} 2$ density. Moreover, you apply it to a mixture of $\mathrm{CO} 2$ and $\mathrm{CO}$, of which there is no knowledge at all.

Following the criticism of the referee, we omitted the density calculations based on the $\mathrm{CO} 2$ Fermi splitting as well as the methods of calculations from the 'Analytical methods'. Thus we rephrased the relevant part of the 'Discussion' accordingly.

Line 53 ---54 (page 3): you have to use the right dimensions for the described parameters. The concentration is given in $\mathrm{mol} / \mathrm{m} 3$. The mass density is given in $\mathrm{kg} / \mathrm{m} 3$. The "absolute concentration of water" is usually given in amount of substance per 106 mole Si. The use of "ppm" and "wt\%" are ot SI, moreover, the combination "ppm wt\%" makes no sense at all. You can give the concentration as $\mu \mathrm{mol} / \mathrm{mol} \mathrm{Si}$ (amount ratio), or $\mathrm{g} / \mathrm{kg} \mathrm{Si}$ (mass ratio).

(also page 7.9 and 10 )

The concentration of $\mathrm{H} 2 \mathrm{O}$ in NAMs (nominally anhydrous minerals) is usually given in "ppm" in the majority of the publications should these concern either experimental or natural samples (i.e. Ingrin \& Skogby, 2000; Green et al., 2010). Even in the fundamental papers concerning the extinction coefficient of $\mathrm{H} 2 \mathrm{O}$ for NAMs in granulites the concentration is always given in ppm (wt. \%) (Bell et al., 1995, 2003; Johnson and Rossman, 2003; Thomas et al. 2009; Maldener et al., 2001). We admit that there are a few number of papers (i.e., Zhao et al., 2004) where the concentration of $\mathrm{H} 2 \mathrm{O}$ is given in $\mathrm{H} / 106 \mathrm{Si}$, however, these papers are rather exceptional than usual from this points of view. We must note that other papers where $\mathrm{H} 2 \mathrm{O}$ concentrations from granulitic NAMs have been reported also reported these in ppm instead of $\mathrm{H} / 106 \mathrm{Si}$ (Yang et al., 2008). The use of $\mathrm{H} 2 \mathrm{O}$ ppm wt.\% is an absolutely adequate way to report the concentration as the term "ppm" itself only stands for "parts per million" but says nothing whether the part is, in fact, volume, piece, weight etc."

Bell, D. R., Ihinger, P. D., and Rossman, G. R., 1995. Quantitative-analysis of trace $\mathrm{OH}$ - in garnet and pyroxenes. American Mineralogist 80, 465-474.

Bell, D. R., Rossman, G. R., Maldener, J., Endisch, D. \& Rauch, F. (2003). Hydroxide in olivine: A quantitative determination of the absolute amount and calibration of the IR spectrum. Journal of Geophysical ResearchçSolid Earth 108, doi:10.1029/2001JB000679.

Green, D. H., Hibberson, W. O., Kovaacs, I. \& Rosenthal, A. (2010). Water and its influence on the lithosphere^asthenosphere boundary. Nature $467,448^{\wedge} 451$. Ingrin, J. \& Skogby, H. (2000). Hydrogen in nominally anhydrous upper-mantle minerals: concentration levels and implications. EuropeanJournal of Mineralogy 12, 
543-570.

Johnson, E. A. and Rossman, G. R., 2003. The concentration and speciation of hydrogen in feldspars using FTIR and H-1 MAS NMR spectroscopy. American Mineralogist 88, 901-911.

Maldner, J., Rauch, F., Gavranic, M., Beran, A., 2001. OH absorption coefficients of rutile and cassiterite deduced from nuclear reaction analysis and FTIR spectroscopy. Mineralogy and Petrology, 71, 21-29.

Thomas, Sylvia-Monique, Koch-Müller, M., Reichrat, P., Rhede, D., Thomas, R., Wirth, R., Matsyuk, S. 2009. IR calibrations for water determination in olivine, r-GeO2, and $\mathrm{SiO} 2$ polymorphs. Physics and Chemistry of Minerals, 36, 489-509.

Yang, X. Z., Deloule, E., Xia, Q. K., Fan, Q. C., and Feng, M., 2008. Water contrast between Precambrian and Phanerozoic continental lower crust in eastern China. Journal of Geophysical Research-Solid Earth 113.

Zhao, Y. H., Ginsberg, S. B. \& Kohstedt, D. L. (2004). Solubility of hydrogen in olivine: dependence on temperature and iron content. Contributions to Mineralogy and Petrology 147, 155-161.

Line 58 (page 3): the uncertainty of $30 \%$ is very high and must be taken into account for each measurement, and not only for the calculated total (Page 7)

We clarified the sentences in question and we provided a detailed explanation on the uncertainty.

Line 6 - 44 (page 4): The description of the rock is incomplete: the petrography of rock forming minerals should also describe the material around xenolites, because you use this information in the following paragraph. Moreover, you should describe here the existence of veins in the xenolites (which is also occurring later in the manuscript). We wrote in the 'Introduction' section that the xenoliths are included in Plio-Pleistocene alkaline basalt and basaltic tuff. We also give some relevant papers in the 'Introduction' and 'Geology' sections, which are dealing with the alkaline basalts in details for interested readers. This is the conventional way of referring to the host rock in papers dealing with xenoliths. The basalts enclosing the xenoliths are out of scope of this paper.

The clinopyroxene-plagioclase vein exists only at the edge of the Sab38 mafic garnet granulite xenolith, which is already described in the 3rd paragraph of the 'Petrography' section and shown on Fig. 2a.

Line $47-60$ (page 4): the description of fluid inclusions is incomplete, and is only based on the analyses of 5 inclusions.

We described altogether 5 types (and NOT five pieces) of fluid and silicate melt inclusions in our xenoliths based on their textural position, host mineral and appearance. Each type contains numerous inclusions. We described them in the text, we showed the main types in Fig 3. and we made a summary in the Table 1. We follow this line throughout the paper. I simply cannot understand why the referee thinks that the description and the discussion are based on 5 inclusions.

If the referee thinks that we analysed only 5 fluid and melt inclusions, we can refute this statement as well. It is true, that we could not measure the bubbles of melt inclusions and the fluid inclusions with microthermometry, due to their small size and dark appearance. However we made35 successful Raman spectroscopic measurements on inclusion contents (Table 3), which allowed us to characterize the composition of the different generations properly. Furthermore we made 89 IR point analyses on minerals in different textural positions (see Table 4), and 12 IR profiles across clinopyroxene and plagioclase grains with 111 point analyses altogether to characterize the water content of the minerals and the distribution of the water in the minerals (We wrote the latter number in the capture of the Fig.4).

Table 1 is not informative.

Table 1 summarizes and helps the reader understand the characteristics of the five groups of fluid and silicate melt inclusions found in different host minerals of the two xenoliths.

You do not give any images of the inclusions.

Please refer to Fig. 3 and Fig. 4, there are plenty of inclusions there.

You do not give arguments for "primary".

We amended our description with "arguments" for primary inclusions.

You do not describe the individual types of fluids. How can you describe 3 types of 
fluids based on the analyses of 5 inclusions?

We observed numerous $\mathrm{FI}$ in the two samples, which allows us to make these 5 groups, see Table1. The Raman analyses were successful on 35 inclusions (Table3), not only on 5 , which is the number of the genetical groups, based on detailed petrography.

Line 1 to 16 (page 5): mistakes in English grammar and sense

1 "but sometimes the size goes up"

2 "however decrepitation is not observe"

3. "with lear signs"

4. "their size is usually"

5. "this SMI always decrepitated" etc... answers: a size may vary in numbers, decrepitation is a process, you may only see the results of it (as microcracks?) "clear" is subjective, "usually" means that I can sometimes observe an other size of the same inclusion

We corrected the sentences in question.

Line 19 - 53 (page 5): the variation in composition of garnets, pyroxenes and plagioclases are not supported by the presented data. And what is a "textural position"? it does not exist.

We selected representative mineral analyses from each compositional groups and we gave compositional ranges expressed in relevant end members in the text. In the case of garnets we wrote, that the chemical compositions of the garnets in the two studied xenoliths are somewhat different. This is presented by representative analyses from both xenoliths in Table 2. The same applies to pyroxenes and plagioclases. Please compare Table 2 with the "Mineral chemistry" section.

Textural position of a mineral or a mineral assemblage means different looking minerals or mineral assemblages, which may represent different generations according to the commonly accepted terminology of the conventional metamorphic petrography. If we can put the minerals and mineral assemblages of different textural position in relative order, we can establish a metamorphic history for a given rock. In our case please refer to the Fig. 2, where we show the wall rock and the vein or melt pockets which represent mineral assemblages in different textural position. Furthermore we observed plagioclase in two different textural positions (SMI free small ragged relics and SMI bearing big ones with slightly curved boundaries) in the vein of the Sab38 xenolith (Fig. 2b). This observation helps us to determine two generations of plagioclase in the clinopyroxene-plagioclase vein.

Line 57 - 60 (page 5): the electron microprobe analyses of SMI does not get to $100 \%$, so that element is missing in the analyses? Neither oxygen nor hydrogen is detected in common microprobe practice. The water content of the melt is always "missing" from the microprobe totals as well as trace elements.

Line 2 (page 6): English: "changes" is not the correct word, should be "vary". But, you also have to describe what the difference is.

We corrected as the referee suggested. The difference is written in the text. Some of the silicate melt inclusions have trachybasaltic, some of them have trachydacitic composition.

Line 7 (page 6): "error margin" = uncertainty

We corrected as the referee suggested.

Line $15-52$ (page 6): as mentioned above, this paragraph is base $d$ on the analyses of 5 fluid nclusions and 4 melt inclusions, that cannot be a seriousattempt to use this technique for geological interpretations. As mentioned above, there are 5 groups of FI and SMI (Table 1) and we analysed 35 inclusions (8 FI and 27 SMI, Table 3) with Raman spectroscopy, which is sufficient for the compositional characterization of the different fluid and melt inclusion generations.

Page 7: "ppm wt\%" has no meaning, see comment above.

See reply above.

Line 56 - 57 (page 7) Here you suddenly describe fluid inclusions from the wall rock. In table 3 you only mentioned one melt inclusions.

We corrected that.

There is a lot of information missing, and there is a lot of improperly mixing of

information (refereeing to data that does not exist, or that is appointed to another rock). 
Unfortunately the referee did not specify the problems concerned. However we looked through our discussion and made some changes to clarify our main points.

Paragraph"Discussion": the argumentation of many statements can be easily used for completely other conclusions.

Unfortunately the referee did not give us the possible alternatives, thus we cannot argue in favour of our conclusions. However I am very curious how could the referee explain alternatively the higher water content of the vein and melt pool minerals or the compositional changes in the fluid inclusions and the bubbles of the silicate melt inclusions.

Page 8 contains many sentences that must be improved in English. Although the referee did not specify these sentences, we improved the language of the discussion. 
Melting, Fluid Migration and Fluid-Rock Interactions in the lower crust beneath the Bakony-Balaton Highland Volcanic Field: a Silicate Melt and Fluid Inclusion Study

Németh $\mathrm{B}^{1,2}$, Török $\mathrm{K}^{1}$, Kovács $\mathrm{I}^{1}$, Szabó $\mathrm{Cs}^{2}$, Abart $\mathrm{R}^{3}$, Dégi $\mathrm{J}^{1}$, Mihály $\mathrm{J}^{4}$ \& Németh $\mathrm{Cs}^{4}$

${ }^{1}$ Geological and Geophysical Institute of Hungary, $H-1143$, Stefánia út 14, Budapest, Hungary e-mail: bianca.nemeth@gmail.com, phone: +36-1-9202-382

${ }^{2}$ Lithosphere Fluid Research Lab, Institute of Geography and Earth Sciences, Eötvös University, Budapest, Hungary, H-1117, Pázmány Péter sétány 1/c

${ }^{3}$ Department of Lithospheric Research, University of Vienna, Althanstraße 14, 1090 Vienna

${ }^{4}$ Institute of Molecular Pharmacology, Research Centre for Natural Sciences, Hungarian Academy of Sciences, $\mathrm{H}-1117$, Magyar tudósok körútja 2., Budapest, Hungary

Keywords: granulite xenolith, partial melting, silicate melt inclusions, fluid inclusions, IR analyses, Pannonian Basin

\section{$\underline{\text { Abstract }}$}

Plio-Pleistocene alkali basalt hosted mafic garnet granulite xenoliths were studied from the BakonyBalaton Highland Volcanic Field (BBHVF) to trace fluid-melt-rock interactions in the lower crust. Two unique mafic garnet granulite samples were selected for analyses (optical microscopy, microthermometry, electron microprobe, Raman and IR spectroscopy), which contain clinopyroxene-plagioclase vein and patches with primary silicate melt inclusions (SMI). The samples have non-equilibrium microtexture in contrast with overwhelming majority of previously studied mafic garnet granulite xenoliths. Primary silicate-melt inclusions were observed in plagioclase, clinopyroxene and ilmenite in both xenoliths. The SMI-bearing minerals located randomly in Mi26 and in a clinopyroxene-plagioclase vein on the edge of Sab38 granulites. Petrography, fluid and melt inclusion study suggests that at least three fluid events occurred in the deep crust represented by these xenoliths.

1. Primary $\mathrm{CO}_{2}$-dominated $\pm \mathrm{CO} \pm \mathrm{H}_{2} \mathrm{~S}$ fluid inclusions were observed in the wall-rock part of Sab38 xenolith.

2. The crystallization of new clinopyroxene from melt, with $\mathrm{CO}_{2}+\mathrm{H}_{2} \mathrm{O}$ fluid.

3. The crystallization of new plagioclase occurred in a heterogeneous fluid-melt system with additional $\mathrm{N}_{2}$ and $\mathrm{CH}_{4}$ during crystallization. A local reaction was observed between sphene and acidic melt, which formed ilmenite+clinopyroxene+plagioclase \pm orthopyroxene.

The 'water' content of the rock forming minerals was determined by infrared spectroscopy. The calculated bulk 'water' content of the Mi26 xenolith is $171 \pm 51 \mathrm{ppm}$ wt. \%. The bulk wall rock part of the Sab38 granulite contains $55 \pm 17 \mathrm{ppm}$ wt. \% of 'water', whereas the bulk plagioclase-clinopyroxene vein contains $278 \pm 83 \mathrm{ppm}$ wt. $\%$. These results imply a very dry lower crust, locally hydrated by percolating fluids and melts.

\section{Introduction}

The Pannonian Basin (PB) includes several xenolith localities hosted by Plio-Pleistocene alkaline basalts, where several kinds of ultramafic, mafic and other kinds of xenoliths from different depths of the lithosphere were found and studied (e.g. Embey-Isztin 1976; Török 1995; Török et al. 2005). Beyond the abundant ultramafic deep lithospheric xenoliths in the Bakony-Balaton Highland Volcanic Field (BBHVF), garnet clinopyroxenite and lower crustal mafic garnet granulites and metapelite xenoliths were discovered and studied in details by e.g. Embey-Isztin et al. 1990, 2003; Dégi et al. 2009, 2010; Török 1995, 2012; Török et al. 2005. According to systematic paleo-thermobarometry by Dégi (2009) lower crustal mafic garnet granulite xenoliths represent a continuous lithostratigraphic profile with a paleo-depth range from 35 to $58 \mathrm{~km}$ under the BBHVF. Presently the crust beneath the BBHVF is thinner than $35 \mathrm{~km}$, thus the xenoliths offer a unique insight into the evolution of a lower crustal section. Although most of the lower crustal mafic granulites show equilibrium microtextures, locally some disequilibrium domains representing later reactions such as dehydration melting of hydrous minerals (amphibole and biotite) (Török et al. 2007), reaction between sphene and melt (Németh et al. 2011) or breakdown reactions of garnet (Dégi et al. 2010) occur in the xenoliths. The latter reaction shows a decrease of pressure in the lower crust which is related to the thinning of the lithosphere related to the Neogene tectonic evolution of the PB (Horváth et al. 2006) and account for the higher paleo-temperatures and pressures (Török et al. 2005). Besides the above mentioned first two reactions, several generations of fluid inclusions show evidence of multiple fluid and melt migration and fluid/melt-rock interactions (Dégi and Török 2003; Török 1995, 2012; Török et al. 2005). The term 'fluid-rock interaction' will be used for fluid/melt -rock interaction through out the paper.

Although these reactions and fluid inclusions serve as textural evidence for melting and melt-rock interaction, direct evidence for the presence of melt, e.g. silicate melt inclusions were not observed so far. In this study we focus on some rare samples, which contain silicate melt inclusions. Our goal is to describe the nature, and define the evolution of fluids and melts migrating, as well as interaction with the lower crust with a special attention paid to the distribution of 'water' in the rock forming minerals. After studying several hundreds of thin 
sections of lower crustal garnet granulite xenoliths from the BBHV we found only two samples, (Sab38 and Mi26) which contain silicate melt inclusions in their rock forming minerals (plagioclase, clinopyroxene). These xenoliths were collected at Káptalantóti (Sabar-hegy) and Mindszentkálla, respectively.

Petrography reveals the mineral associations, different stages of fluid-rock interactions and gave a relative timing of events. The mineral chemistry provides an opportunity for the geothermo-barometric calculations to determine the equilibrium pressure and temperature of the garnet granulitic assemblages. We applied fluid inclusion microthermometry and Raman microspectroscopy to determine the composition of the FIs and the bubble of the SMI. Infrared (FTIR) spectrometry was applied to define the 'water' content of minerals with and without melt and fluid inclusions, in order to assess the distribution and role of 'water' in lower crustal fluid-rock interactions.

\section{Geology}

The PB is built up by the ALCAPA (ALpian-CArpathian PAnnonian) and the Tisza-Dacia units (Fig.1a). The ALCAPA, northern tectonic block, was extruded from the Alps during the Late Oligocene-Early Miocene (Kázmér and Kovács, 1985). The driving force of this mechanism was collision between the stable European Platform and the Adriatic block (Csontos and Vörös, 2004; Fodor et al. 1999). Extrusion of the ALCAPA was accompanied by two extensional stages (Fodor et al. 1999; Huismans et al. 2001). The first rifting phase (18-14 Ma) was characterized by NE-SW tension directions (Fodor et al. 1999). The rate of the thinning was nearly the same in the crust $(\beta)$ and in the mantle lithosphere $(\delta)(\beta=\delta=1.4-1.6$, Huismans et al. 2001$)$. Widespread calc-alkaline and rare ultrapotassic volcanism accompanied this extensional phase in the Middle Miocene (Harangi et al. 1995, Kovács and Szabó 2008; Lexa et al. 2010). The thinning of the crust was negligible $(\beta=1.1)$ compared to the thinning of the mantle lithosphere $(\delta=4-8)$ in the second rifting phase $(12-$ $11 \mathrm{Ma}$ ) (Huismans et al. 2001). Török (2012) calculated a somewhat higher cumulative thinning factor of 2.3-3.4 for the lower crust on the basis of the phase reactions in lower crustal mafic granulite xenoliths beneath the BBHVF.

The Plio-Pleistocene sporadic alkali basaltic volcanism started in the western and middle part of the PB at about 11.5 Ma (Balogh et al. 1990), contemporaneously with the second extensional phase (Huismans et al. 2001). The volcanic activity later moved to the north and east and ended in the Persány Mts. at 0.7-0.5 Ma (Panaiotu et al. 2004) and at 0.4 Ma in the Nógrád-Gömör volcanic area (Balogh et al. 1986; Lexa et al. 2010).

The BBHVF is located in the central PB on the ALCAPA tectonic block (Fig.1b). This volcanic area is the richest in lower crustal xenoliths compared to the other alkaline basaltic areas (i.e. Nógrád-Gömör, Persány, Little Hungarian Plain, Styrian Basin). Crustal xenoliths were found in six locations: Kapolcs (Áldozó-tetö; Bondoró-hegy), Mindszentkálla, Káptalantóti (Sabar-hegy), Szentbékkálla, Szigliget and Tihany. The dominant lower crustal xenoliths are mafic granulites (Dégi and Török 2003; Dégi et al. 2009, 2010; Dobosi et al. 2003; Embey-Isztin et al. 1990, 2003; Kempton et al. 1997; Török et al. 2005), rarely some metasedimentary and felsic ones also occur (Embey-Isztin et al. 2003 Németh et al. 2009; Török 2002, 2012, Török et al. 2014). Mafic granulite xenoliths from the BBHVF were described by Embey-Isztin et al. (1990). Kempton et al. (1997) Dobosi et al. (2003) and Embey-Isztin et al. (2003) analyzing the whole rock for trace element, radiogenic and stable isotopes. On the basis of rare earth elements and stable isotope composition, it was assumed that the protolith may have been oceanic pillow basalt, which suffered a granulite facies metamorphism during the Alpine orogenesis.

Two types of mafic granulites were observed and discerned based on the rock-forming mineral assemblage (e.g. Török et al. 2005). The "dry" granulites contain the assemblage clinopyroxene + garnet + plagioclase \pm orthopyroxene \pm quartz \pm scapolite. The average modal composition of these granulites is 55 vol. $\%$ clinopyroxene, 25 vol. \% garnet and 15 vol. \% plagioclase with 5 vol. \% of oxides. The "wet" granulites contain additional hydrous minerals such as amphibole and/or biotite. The amount of the hydrous minerals varies from 1 vol. $\%$ to 15 vol. $\%$. the BBHVF:

The previous studies revealed the main stages of the metamorphic evolution of the lower crust beneath

(1) The primary mineral assemblages preserved the pre-Miocene overthickened Alpine orogenic root down to about $57 \mathrm{~km}$ depths at temperatures of $800-1100{ }^{\circ} \mathrm{C}$ (e.g. Dégi et al. 2010; Török 1995; Török et al. 2005).

(2) During the Miocene extension of the basin, partial melting of the biotite-bearing mineral assemblage took place due to the infiltration of $\mathrm{CO}_{2}$-rich fluids. The produced melts were percolating in the lower crust during the extension of the Pannonian Basin. These melts reacted with primary minerals to form new mineral assemblages at different pressures. The isochemical breakdown reaction of garnet to form orthopyroxene, anorthite and spinel symplectite indicates a significant pressure decrease which is due to the crustal thinning during the extension. During this extension stage the crust was thinned from the original Alpine root thickness of 55-60 km to the present day 30-34 km (Posgay et al. 1991; Dégi et al. 2010; Török 1995; Török et al. 2005; Kovács and Szabó 2005). 
(3) Eventually, a short interaction (9-20 hours) occured between the xenoliths and the host alkaline basalts during uplift according to diffusion modelling of complex chemical zoning patterns in titanomagnetites (Dégi et al. 2009).

\section{Analytical methods}

The major element composition of the minerals of the xenoliths was measured by Cameca SX-100 type electron microprobe equipped with wavelength-dispersive spectrometers at the Vienna University, Institute of Earth Sciences and by EDAX PV 9800 energy-dispersive spectrometer equipped AMRAY 1830 I/T6 type electron microprobe at the Eötvös University Budapest. The accelerating voltage was $20 \mathrm{keV}$ and the beam current was $20 \mathrm{nA}$. The electron beam diameter changed between 1-5 microns. Synthetic and natural mineral standards and ZAF correction were applied for the precise quantitative determination of elements.

The average uncertainty with EDS to the different elements are \pm 2 sigma (wt. \%), which numerically means the following average ones: $\mathrm{Al}_{2} \mathrm{O}_{3}- \pm 0.26 ; \mathrm{SiO}_{2}- \pm 0.46 ; \mathrm{MgO}- \pm 0.14 ; \mathrm{Na}_{2} \mathrm{O}- \pm 0.11 ; \mathrm{CaO}- \pm 0.13$; $\mathrm{FeO}- \pm 0.19 ; \mathrm{K}_{2} \mathrm{O}- \pm 0.03 ; \mathrm{MnO}- \pm 0.03 ; \mathrm{TiO}_{2}- \pm 0.03 ; \mathrm{Cr}_{2} \mathrm{O}_{3}- \pm 0.01$.

Phase transformations in fluid inclusions were studied with a Linkam THM600 heating-cooling stage on a Nikon Eclipse LV100Pol polarizing microscope at the Lithosphere Fluid Research Lab /LRG/, Eötvös University, Hungary. The stage was calibrated using Raman-analysed $\mathrm{CO}_{2}-\mathrm{H}_{2} \mathrm{O}$ natural inclusions. At the melting point of the $\mathrm{CO}_{2}$, the reproducibility of the temperature was $\pm 0.2{ }^{\circ} \mathrm{C}$.

A HORIBA JobinYvon Labram HR800 type spectroscope was applied for Raman microspectroscopy in the FFI Raman Laboratory at Eötvös University, Budapest, Hungary. This equipment is a high-resolution confocal Raman microspetrometer, operating based on the dispersive concept and using edge filters. The wavelength was $532 \mathrm{~nm}$ on Nd-Y-Al garnet (Nd-YAG) double-frequented DPSS laser with $100 \mathrm{~mW}$ laser power at the source and the collection time compared to the sensitivity of the detector was set to maximum. 50x objective was used to analyse silicate melt and fluid inclusions at room temperature, and also in the case of the $150{ }^{\circ} \mathrm{C}$ experiments. The analytical setting included 0 to D0.6 filter, 50-100 $\mu \mathrm{m}$ confocal hole, 1800 spectrograph grating, 3x accumulations and 50-100 sec acquisition time. We used a Linkam stage as special accessory to determine the $\mathrm{H}_{2} \mathrm{O}$-content with microthermometry measurements. Based on the Raman method of Berkesi et al. (2009), spectra were taken both at room temperature and at $150{ }^{\circ} \mathrm{C}$. To heat the inclusions we used the same Linkam heating-freezing stage as was used for microthermometry. At high temperatures the distribution of dissolved $\mathrm{H}_{2} \mathrm{O}$ in $\mathrm{CO}_{2}$ is presumably uniform, which allows (semi-) quantification of spectra of the $\mathrm{CO}_{2}$-rich phase according to the method of Dubessy et al. (1992).

Individual measurements to analyse IR active components $\left(\mathrm{H}_{2} \mathrm{O}, \mathrm{OH}^{-}, \mathrm{CO}_{2}\right)$ in host phases and inclusions were performed using a Fourier transform infrared (FTIR) spectrometer (Varian FTS-60A) coupled to an UMA-600 IR microscope in the Research Centre for Natural Sciences of the Hungarian Academy of Sciences. The term 'water' refers to $\mathrm{H}^{+}, \mathrm{OH}^{-}$and $\mathrm{H}_{2} \mathrm{O}$ species in general. The analyses were done using unpolarized infrared light. Infrared spectra of these minerals were obtained between 4000 and $400 \mathrm{~cm}^{-1}$, using a maximum of $70 \times 70 \mu \mathrm{m}$ aperture size. The samples were measured with a Globar light source, $\mathrm{KBr}$ beam-splitter and an MCT detector. 256 scans were accumulated from each spectrum with $4 \mathrm{~cm}^{-1}$ resolution in the fixed spectral interval where the most important absorption bands related to structurally bound 'water' occur. During the measurements the sample chamber was constantly flushed with compressed air reducing the background created by atmospheric water and carbon.

A recently developed method (Kovács et al. 2008; Sambridge et al. 2008) for unpolarised infrared light makes it possible to determine the concentration of 'water' from a number $(n>5)$ of unoriented anisotropic crystals with good accuracy. This method could only be applied for strongly anisotropic minerals (e.g. olivine, calcite), if the maximum linear unpolarized absorbance is less than 0.15 . Total polarised absorbance $\left(A_{\text {tot }}\right)$ is estimated as three times the average unpolarized absorbance. The estimation is more accurate if as many as possible unoriented grains are considered for the calculation of the average integrated unpolarized absorbance, but could be used with only a couple of unoriented grains if the anisotropy is weak (i.e. for pyroxenes and plagioclase see Xia et al. 2013). The $A_{\text {tot }}$ is then converted to absolute concentration of 'water' (ppm wt. \%) using the calibration factors of Johnson and Rossman (2003) for feldspar, Bell et al. (1995) for ortho- and clinopyroxene and Thomas et al. (2008) for quartz. The uncertainty of the individual measurements of integrated absorbance is usually within 3\%, the thickness of the sample (further 3\%), baseline correction (further 5\%) and the calibration factors may be sources of further 10\% uncertainty. Based on prior experience (Kovács et al. 2008; 2012), however, this overall uncertainty in the absolute concentration of 'water' usually should not exceed $30 \%$. Profiles were also recorded in plagioclase and clinopyroxene, to monitor the variation of the 'water' content with the V- (vapour dominated) and G- (glass dominated) types of SMIs and the host minerals. These measurements bear more quantitative uncertainties, because the profiles were recorded in a singe indicatrix direction with respect to the incident light. The relative variation in absorbance can truly reveal the variation of 'water' content in the vicinity of fluid and melt inclusions. 
The major rock-forming minerals of the two studied lower crustal mafic garnet granulite xenoliths (Sab38, Mi26) are plagioclase, clinopyroxene and garnet \pm orthopyroxene. The main accessory phases are sphene and ilmenite, minor rutile and quartz were also observed in the samples. The melt of the enclosing alkali basalt generally forms thin films along the grain boundaries and small glassy melt pockets.

The Sab38 sample can be divided into two, well-defined parts (Fig.2a). The wall rock part of the thin section consists of garnet granulite with 24 vol. \% garnet, 38 vol. \% plagioclase and 38 vol. \% clinopyroxene modal proportion. The garnets show xenoblastic fabric and mainly observed as dark pseudomorphs. Sometimes relics of garnet are found surrounded by a thick symplectitic plagioclase-orthopyroxene-spinell rim. The plagioclase and the clinopyroxene form often xenoblasts with irregular grain boundaries and embayments. Straight grain boundaries referring to equilibrium crystallisation are found rarely.

A thin $(0.6-0.9 \mathrm{~cm})$ vein, composed of clinopyroxene and plagioclase with accessory quartz, ilmenite and sphene, can be observed also in the sample. Distribution of the two main phases is approximately equal in the vein. Only this part of the xenolith contains primary SMIs in plagioclase and clinopyroxene (Fig.2a). The SMIfree plagioclase grains are small $(0.027 \mathrm{~mm}-0.135 \mathrm{~mm})$ and have amoeboid shapes. The SMI-bearing plagioclase grains are larger $(0.240 \mathrm{~mm}-0.920 \mathrm{~mm})$, and have curved grain boundaries and irregular shape (Fig.2b). Plagioclase grains, hosting SMI, make up 45 vol. \% of the plagioclase population in the whole vein. In contrary to the plagioclase no petrographic difference was observed between the inclusion-free and the inclusion-bearing pyroxenes. Among the accessory phases ilmenite also contains primary SMIs. The breakdown of sphene to ilmenite and clinopyroxene is observed in the vicinity of clinopyroxene-plagioclase-rich vein.

The Mi26 xenolith has predominantly non-equilibrium microtexture (Fig.2c) and a modal composition of 50 vol. \% garnet, 33 vol. \% clinopyroxene and 16 vol. \% plagioclase and 1 vol. \% accessories such as orthopyroxene, sphene and ilmenite. Most of the garnets are replaced by a symplectitic intergrowth of plagioclase-orthopyroxene-spinell. They show embayments in their grain boundaries and have irregular shape (Fig.2c). In most cases, plagioclase surrounds the garnet relics with symplectites. Clinopyroxene is observed on the opposite side of plagioclase (Fig.2c). The plagioclases also have irregular grain boundaries, with embayments. Merely a few domains showing equilibrium microtextures remained in the xenolith. These equilibrium domains usually consist of garnet and clinopyroxene with straight grain boundaries (Fig.2c).

The SMI-containing clinopyroxene and plagioclase rich parts are distributed randomly in the whole rock forming clinopyroxene-plagioclase domains, which make up approximately 33 vol. $\%$ of the xenolith (Fig.2d). The distribution of these two minerals is almost equal in the domains. Consumption of previous garnet in the vicinity of these domains is observed in the xenolith Mi26. Away from the clinopyroxene-plagioclase domain embayed and ragged symplectitic pseudomorphs after garnet relics appear. In this domain the garnets were partially consumed in the fluid-rock interaction and subsequently these relics reacted to form orthopyroxeneplagioclase-spinel symplectitic pseudomorphs. The breakdown of sphene to ilmenite and clinopyroxene is also observed in the vicinity of clinopyroxene-plagioclase-rich domains (Fig.2d).The main accessory is ilmenite, which also contains primary SMI similarly to Sab38. Thin glass films along the grain boundaries and small glassy melt pockets indicate the latest melt-rock interaction by the enclosing basalt.

\subsection{Fluid and melt inclusion petrography}

We have found fluid- (FI) and silicate melt inclusions (SMI) in the studied xenoliths. We found both primary and secondary fluid inclusions and primary silicate melt inclusions. However in this study we consider only the primary fluids in the host granulite and in the newly formed minerals during the fluid -rock interaction. Primary fluid inclusions occur solitarily or in groups (Roedder 1984) scattered among primary silicate melt inclusions found in the core of the plagioclase (Fig. 3a). According to their mode of occurrence we distinguished three types of primary FI. The first type (type I) was entrapped without coexsisting SMI, while type II represents coexisting FI and SMI. We also distinguish a third type of FI (type III), which occurs in plagioclase of the wallrock garnet granulite of sample Sab38.

All types of FIs have mostly spherical or rounded negative crystal shape. They have dark colour and only one gas phase was recognized in the FIs at room temperature. Their sizes are up to $10 \mu \mathrm{m}$.

In Mi26 xenolith, the type I FI occurs only in clinopyroxene, and the type II FI occurs only in plagioclase (Table 1). Also, type I FI was observed in the vein plagioclase of Sab38. Type II FIs are hosted in both clinopyroxene and plagioclase of the vein (Table 1).

We distinguished two types of primary SMI in plagioclase, a colourless glass dominated SMI (containing 70-100 vol. \% glass) and a volatile dominated black one with smaller amount of glass (up to 30 vol. \%), referred to as type $\mathrm{G}$ and type V, respectively (Fig.3a, b). The type G SMIs generally have one or more vapour-rich bubbles (up to 30 vol. \%) (Fig.3b). The vapour bubble in the plagioclase-hosted SMI has dark appearance at room temperature. The size of the SMIs are generally between 15-30 $\mu$ m (Fig.3a, b, c), but sometimes it may 
vary from 15 to $100 \mu \mathrm{m}$ (Fig.3b). Both type G and type V SMI show approximately negative crystal shape. Type G SMIs' boundary may be slightly ragged, however decrepitated inclusions are not observed. The type V SMIs are dark with evident signs of decrepitation. Their size is between 20 and $50 \mu \mathrm{m}$ (Fig.3b).

The clinopyroxene-hosted SMIs consist of brown glass (95-100 vol. \%) \pm bubble. These SMIs are always decrepitated with ragged boundaries and a decrepitation halo of small inclusions around. Their size is usually between 20-30 $\mu \mathrm{m}$ (Fig.3c). The bubble contains two phases $(\mathrm{L}+\mathrm{V})$ at room temperature (Fig.3c). The liquid phase is dominating: around 60 vol. $\%$ on average.

Primary, rounded or oval SMI was also trapped in ilmenite. Signs of decrepitation are not observed in these SMIs, they have sharp boundaries. (Fig.3d). These SMIs consist of glass \pm bubble (10 vol. \%). Their size are typically around $30 \mu \mathrm{m}$. Occurrence of different types of inclusions is summarized in Table $\mathbf{1}$.

Garnets

\section{Mineral chemistry}

The garnets are pyrope-almandine-grossular solid solutions with a small amount of spessartine. The chemical compositions of the garnets in the two studied xenoliths are somewhat different (Table 2). The composition of garnet is $\mathrm{Py}_{20.8} \mathrm{Alm}_{57.3} \mathrm{Gro}_{20.7} \mathrm{Sps}_{1.14}$ in the Mi26 xenolith, whereas in the wall-rock of Sab38 xenolith, garnet has the following chemical compositions: $\mathrm{Py}_{27.9-29.7} \mathrm{Alm}_{49.3-51.00} \mathrm{Gro}_{18.3-18.6} \mathrm{Sps}_{2.4-2.8}$.

\section{Pyroxenes}

The majority of pyroxenes is clinopyroxene. The SMI-free $\left(\mathrm{En}_{32.96-36.04} \mathrm{Wo}_{42.31-45.50} \mathrm{Fs}_{20.12-22.98}\right)$ and SMIbearing $\left(\mathrm{En}_{34.23-34.98} \mathrm{Wo}_{42.75-43.89} \mathrm{Fs}_{21.80-22.37}\right)$ clinopyroxenes have similar chemical compositions in the xenolith Mi26. In the xenolith Sab38, the SMI-bearing clinopyroxenes in the vein have the highest ferrosilite content: $\mathrm{En}_{32.40-32.96} \mathrm{Wo}_{41.29-41.87} \mathrm{Fs}_{25.25-26.32}$. The SMI-free clinopyroxenes in the vein are poorer in ferrosilite $\left(\mathrm{En}_{35.08-}\right.$ $\left.{ }_{36.57} \mathrm{Wo}_{44.44-45.38} \mathrm{Fs}_{18.74-19.92}\right)$ than those in the wall rock, $\left(\mathrm{En}_{34.31-36.83} \mathrm{Wo}_{41.86-44.07} \mathrm{Fs}_{19.23-23.83}\right)$.

The $\mathrm{Al}_{2} \mathrm{O}_{3}$ content of the clinopyroxene in Mi26 xenolith, changes between 2.2-3.7 wt. \%. The SMIbearing clinopyroxenes have zoning just around the SMI. In a 1-2 micrometer wide ring around the SMI, we observed elevated $\mathrm{Si}$-contents in the tetrahedral position $(\mathrm{Si}=2.00-1.97)$, as well as elevated mg-numbers $\left(\# \mathrm{mg}_{(\mathrm{Fetot})}=0.74-0.76\right)$. The clinopyroxene contains more $\mathrm{Al}$ in the tetrahedral position $(\mathrm{Si}=1.94)$ and the $\mathrm{mg}$ number becomes lower $\left(\# \mathrm{mg}_{(\mathrm{Fetot})}=0.60-0.61\right)$ away from the SMI, than next to it.

In the clinopyroxene-plagioclase vein of $\mathrm{Sab} 38$ xenolith the $\mathrm{Al}_{2} \mathrm{O}_{3}$ content changes between 3.1-3.7 wt. $\%$. In the wall rock part of the xenolith $\mathrm{Sab} 38$, the $\mathrm{Al}_{2} \mathrm{O}_{3}$ content of clinopyroxene is higher than in the vein. It varies between 4.0-4.5 wt. \% (Table 2).

Orthopyroxene is found in the wall-rock part of xenolith Sab38 with the following chemical composition: $\mathrm{En}_{51.40-53.77} \mathrm{Wo}_{2.23-2.57} \mathrm{Fs}_{43.69-46.15}$ (Table 2).

Feldspars

The chemical composition of the plagioclases depends on their textural positions (Table 2). The SMIbearing plagioclases in xenolith Mi26 are less albitic, $\left(\mathrm{Ab}_{40.3-49.9} \mathrm{An}_{47.5-57.9} \mathrm{Or}_{1.8-3.3}\right)$ than the SMI-free plagioclases $\left(\mathrm{Ab}_{49.3-56.5} \mathrm{An}_{39.7-47.5} \mathrm{Or}_{2.5-4.3}\right)$. The plagioclases next to clinopyroxene-ilmenite overgrowth have the following chemistry: $\mathrm{Ab}_{49.3-50.0} \mathrm{An}_{46.3-47.5} \mathrm{Or}_{3.2-3.8}$.

The SMI bearing and SMI free plagioclases in the clinopyroxene-plagioclase vein of the Sab38 granulite show the most albitic $\left(\mathrm{Ab}_{60.6-66.5} \mathrm{An}_{26.6-36.1} \mathrm{Or}_{3.4-7.2} ; \mathrm{Ab}_{64.5-65.2} \mathrm{An}_{27.6-29.3} \mathrm{Or}_{6.3-7.2}\right.$ respectively) composition. The rock forming plagioclases in the wall-rock part of Sab38 are intermediate $\left(\mathrm{Ab}_{51.1-53.1} \mathrm{An}_{45.2-46.8} \mathrm{Or}_{1.8-2.1}\right)$, and plagioclase next to clinopyroxene-ilmenite overgrowth in the wall rock has the lowest albite content in the sample $\mathrm{Ab}_{44.6-}$ ${ }_{52.6} \mathrm{An}_{44.0-52.0} \mathrm{Or}_{3.4-3.5}$.

\subsection{Chemistry of the silicate melt inclusions}

The major element composition of the glass in the SMI is similar disregarding the nature of host minerals. The total values are consistently low in plagioclase, clinopyroxene, and ilmenite with the following values: 97.0 \pm 0.9 wt. \% (Mi26; Pl; n=49); 96.7 \pm 1.4 wt. \% (Sab38; Pl; n=5); 95.0 \pm 1.0 wt. \% (Mi26; Cpx; n=10); 95.6 \pm 0.3 wt. \%

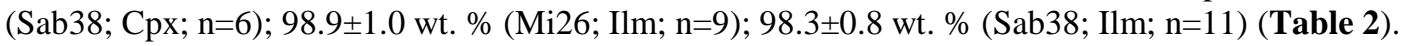

Considering the alkali $\left(\mathrm{Na}_{2} \mathrm{O}+\mathrm{K}_{2} \mathrm{O}\right)$ versus the $\mathrm{SiO}_{2}$, the composition of the glass in the clinopyroxene and the plagioclase hosted SMI is trachydacitic-dacitic-rhyolitic. The composition of the glass in Ilm hosted SMI varies from trachybasaltic to trachydacitic.

\section{Geothermo-barometry}

Thermobarometric calculations were applied on the mineral equilibrium domains of the mafic granulites. The applied thermometer for the temperature estimate was garnet-clinopyroxene thermometer (Ai, 1994) and garnet-clinopyroxene-plagioclase-quartz geobarometer of Eckert et al. (1991) was used for pressure estimation. 
In the garnet-pyroxene-plagioclase-quartz geobarometer, the uncertainty for each reaction is propagated as the square root of the sum of the squares of the standard deviations of the enthalpy and entropy terms (Newton and Perkins, 1982), scaled to the pressure calculation by dividing by $\Delta V_{R}$ (Eckert et al. 1991). For the thermometer, unreliable estimate of $\mathrm{Fe}^{3+}$ content in garnet and clinopyroxene and non-equilibrium between garnet and clinopyroxene are two major sources of errors in estimating equilibrium temperatures of natural rocks (Ai 1994). The overall error of the $\mathrm{p}-\mathrm{T}$ is an approximate value, which covers and contain each uncertainty of analytical and calculation methods. The uncertainty of the geobarometers is typically within $\pm 1 \mathrm{kbar}$. The uncertainty of the geothermometers is within $\pm 50{ }^{\circ} \mathrm{C}$. Thermobarometry applied to the wall-rock part of xenolith Sab38 provides a temperature of $820-860{ }^{\circ} \mathrm{C}$ and a pressure of 11.9-12.1 kbar. In xenolith Mi26, the equilibrium garnetclinopyroxene-plagioclase domains suggest $915-930{ }^{\circ} \mathrm{C}$ temperature, and 11.6-12 kbar pressure.

7. Microthermometry and Raman analyses of fluid and silicate melt inclusions

Microthermometry was successfully used only on two one-phase bubbles from plagioclase-hosted SMI in xenolith Sab38. The final melting point is in the range of $-59.6--60.2{ }^{\circ} \mathrm{C}(\mathrm{n}=2)$, and the homogenization temperature is $8.7{ }^{\circ} \mathrm{C}(\mathrm{n}=1)$. Other FI and bubbles in both types of SMI were too dark to measure under the microscope.

Raman spectroscopy was undertaken at room temperature on all types of FI and bubbles in SMI for determining the composition of the fluid. To enable the detection of small amounts of 'water' the measurements were repeated at $150^{\circ} \mathrm{C}$.

The chemical composition of the plagioclase hosted type I FI in the plagioclase-clinopyroxene vein of xenolith Sab38 is 66 - 76 mol. \% $\mathrm{CO}_{2}+24-30$ mol. \% $\mathrm{CO} \pm 0-3$ mol. \% $\mathrm{H}_{2} \mathrm{O} \pm$ less than 1 mol. \% $\mathrm{CH}_{4}, \mathrm{H}_{2} \mathrm{~S}$ and $\mathrm{N}_{2}$ at room temperature. A different chemical composition was detected in the plagioclase hosted type II FI (Table 3). These FI contain 90 - 99 mol. $\% \mathrm{CO}_{2}+1-10 \mathrm{~mol} . \% \mathrm{CO} \pm<0.5$ mol. $\% \mathrm{H}_{2} \mathrm{~S}$ at room temperature (Table 3). For the type G SMI, the bubbles in the plagioclase hosted SMI in the vein of xenolith Sab38 contain 88 - 100 mol. $\% \mathrm{CO}_{2} \pm 0-7.6 \mathrm{~mol} . \% \mathrm{CO}$ and 0-4.3 mol. $\% \mathrm{~N}_{2}$ at room temperature. In the clinopyroxene-hosted type G SMI, the bubble contains 99.8 - 100 mol. \% $\mathrm{CO}_{2} \pm 0-0.2 \mathrm{~mol}$. \% CO at room temperature.

Type III FIs were observed in the wall-rock part of the xenolith Sab38 (Table 3). In plagioclase, the primary FI contains 86 mol. $\% \mathrm{CO}_{2}+14$ mol. $\% \mathrm{CO}+$ less than $0.5 \mathrm{~mol} . \% \mathrm{H}_{2} \mathrm{~S}$ at room temperature. Its 'water' content is below the detection limit at room temperature.

The type I FI in SMI-free clinopyroxene in Mi26 granulite contains 99 mol. \% $\mathrm{CO}_{2}$ and less than 1 mol. \% of $\mathrm{N}_{2}$ and $\mathrm{H}_{2} \mathrm{O}$ at room temperature. (Table 3). The type II FIs in plagioclase contain 84-100 mol. \% CO $\mathrm{CO}_{2} \pm 0-10$ mol. \% CO \pm 0-6 mol. \% $\mathrm{N}_{2}$ mixed system (Table 3). On heating 'water' content of fluid inclusions becomes detectable, it varies up to $6.1 \mathrm{~mol} \%$.

In the case of the plagioclase hosted type G SMI from xenolith Mi26, the chemical composition of the bubbles change between 80-100 mol. \% $\mathrm{CO}_{2} \pm$ 0-17 mol. \% $\mathrm{CO} \pm 0-3$ mol. \% $\mathrm{N}_{2}$ mixed components at room temperature (Table 3)., Up to $0.7 \mathrm{~mol} . \% \mathrm{H}_{2} \mathrm{O}$ can be detected in the plagioclase hosted type I SMIs on heating. The bubbles of the clinopyroxene hosted type I SMI consist of 97-100 mol. \% $\mathrm{CO}_{2} \pm 0-2 \mathrm{~mol}$. \% $\mathrm{H}_{2} \mathrm{O} \pm$ less than 1 mol. $\% \mathrm{~N}_{2}$ according to Raman analyses at room temperature. Heating results in somewhat higher 'water' contents of up to $3.3 \mathrm{~mol} \%$. Bubbles of type V SMI in both xenoliths show no detectable components by Raman spectroscopy, they proved to be empty.

\section{$\underline{\text { 8. IR analyses }}$}

We have chosen both FI- and SMI-free and FI- and SMI-bearing minerals for the IR analyses to study the changes of 'water' content in minerals during fluid-rock interactions. We also completed some IR profiles across minerals with FI and SMI to quantify the changes in 'water' content (see Supplementary Material for spectra).

The 'water' content of feldspars is detected by a broad band at $3240 \mathrm{~cm}^{-1}$ and a smaller one at $3450 \mathrm{~cm}^{-1}$. Sometimes the former band has a smaller absorption band at $3550 \mathrm{~cm}^{-1}$ forming a shoulder. In the xenolith Mi26 the 'water' content of the inclusion-free plagioclases changes between 0 (below the detection limit) ppm wt. $\%$ up to $240 \mathrm{ppm}$ wt. $\%$. In the SMI-bearing plagioclases, the 'water' content has an increasing trend from the inclusion-free edge of the grain where the 'water' content is below or close to the detection limit to the SMIbearing part of the mineral. In the last point close to the SMI, the 'water' content increases up to a maximum of 642 ppm wt. \%.

The inclusion-free feldspars in the clinopyroxene-plagioclase vein of xenolith Sab38 contain 'water' around the detection limit: 0-24 ppm wt. \%. The distribution of 'water' in the SMI-bearing plagioclases is similar to that of the SMI-bearing plagioclase in the Mi26 granulite. The SMI-free edge of the grains contain about 3 ppm wt. \% 'water' which increases towards the SMI-bearing part, reaching a maximum of $684 \mathrm{ppm}$ wt. \% in the last point close to the SMI. Plagioclases in the wall-rock part of this xenolith have somewhat higher 'water' content of about 7-59 ppm wt. \%, than the SMI free plagioclases in the vein (Table 4). There is no variation (i.e. diffusion profile) in 'water' content within plagioclase in the wall-rock part of granulite Sab38. We were not able 
to quantify the measurements in the case of SMI, however the value of the integrated band area becomes twiceten times higher in the case of type $\mathrm{V}$ silicate melt inclusion than the peak area of the last inclusion-free point (Fig.4a, b). The 'water' content in the presence of type G SMI increases less strongly than in the presence of a type V SMI (Fig.4c, d). Although the profiles are represented in ppm wt. \% value, we point out that these profiles were recorded only with a single crystal orientation of the minerals, the reported 'water' contents should thus be considered only first order approximations. The observed variations and trends indicated by the curves in (Fig.4b, d) however, reflect real relative variations in 'water' content.

There is no clear absorption band in the $\mathrm{OH}^{-}$-range of garnets (see Supplementary Material), merely interference fringes close to the noise level. This indicates that the 'water' content was under the detection limit in every case.

The 'water' content of clinopyroxene was detected by a distinct absorption band at $3630 \mathrm{~cm}^{-1}$ and a broad band around $3460 \mathrm{~cm}^{-1}$. In xenolith Mi26, the 'water' content of SMI free clinopyroxenes changes between 87 to $271 \mathrm{ppm}$ wt. \%. The SMI-bearing clinopyroxenes show 'water' contents from under the detection limit to 227 ppm wt. \%. The 'water' content of SMI free and SMI-bearing clinopyroxenes varies from 73 to $190 \mathrm{ppm}$ wt. \% and from 155 to $182 \mathrm{ppm}$ wt. \%, respectively in the vein of xenolith Sab38. In the clinopyroxenes of the wallrock part of xenolith Sab38 the 'water' content changes between 29-200 ppm wt. \% (Table 4). Clinopyroxenes show no zoning in the 'water' content.

The 'water' content of orthopyroxene in xenolith Mi26 was detected as broad absorption bands at 3582 and $3456 \mathrm{~cm}^{-1}$ and smaller absorption bands were also observed as shoulders at $3250 \mathrm{~cm}^{-1}$ and at $3701 \mathrm{~cm}^{-1}$ in the OH-range. The amount of the 'water' in orthopyroxene changes between 189-193 ppm wt. \%.

In the $\mathrm{OH}^{-}$-range of the quartz in xenolith $\mathrm{Sab} 38$ a sharp absorption band was observed at $3379 \mathrm{~cm}^{-1}$ and smaller and broad bands were also detected at 3465, 3429 and $3315 \mathrm{~cm}^{-1}$. Inclusion free quartz grains in the clinopyroxene-plagioclase vein of xenolith Sab38 have 51-59 ppm wt\% 'water' content.

We determined the average 'water' content of the samples by using the average 'water' contents for the rock forming minerals (Table 4), and their respective modal compositions (see Petrography section) and the modal proportions of the inclusion free and inclusion bearing minerals. In Mi26 granulite, the SMI-bearing plagioclase makes up 45 vol. \% of the total plagioclase population. In Sab38 granulite, the SMI-bearing plagioclase makes up the same rate, namely 45 vol. $\%$ of the plagioclase population in the whole vein. The modal proportion of the SMI-containing clinopyroxene compared to the SMI free ones is 40 vol. \% in both samples. The calculated 'water' content of the whole xenolith is $171 \pm 51 \mathrm{ppm}$ wt. $\%$ for the Mi26 xenolith. Dividing the SMI-bearing clinopyroxene-plagioclase patches and the garnet granulitic wall-rock, we calculated $413 \pm 124$ ppm wt. $\%$ and $77 \pm 23$ ppm wt. \% respectively. The calculated 'water' content of the wall rock part of Sab38 xenolith is $55 \pm 17 \mathrm{ppm}$ wt. $\%$, whereas the clinopyroxene-plagioclase vein contains more 'water' of about $278 \pm 83$ ppm wt. $\%$.

\section{Discussion}

$9.1 \mathrm{p}-\mathrm{T}$ conditions of formation of garnet granulite

The dominantly non-equilibrium microtexture of the studied granulite xenoliths with a few equilibrium domains is different from the dominantly equilibrium microtexture of other previously observed lower crustal granulite xenoliths (Dégi and Török 2003; Dégi et al. 2009, 2010; Török 1995; Török et al. 2005). The rare equilibrium domains with the garnet-clinopyroxene-plagioclase assemblage, showing straight grain boundaries, represent a former equilibrium garnet granulite assemblage, which is widely known from the lower crustal granulite xenoliths of the BBHVF (Dégi and Török 2003; Dégi et al. 2009, 2010; Török 1995; Török et al. 2005). Accessories in the garnet granulite mineral assemblage are orthopyroxene, quartz and sphene. Equilibrium domains in both studied xenoliths indicate a pressure of about $12 \mathrm{kbar}$ and a temperature of 820-930 ${ }^{\circ} \mathrm{C}$. These conditions are comparable with formation of mafic garnet granulites in the lower crust (e.g.: Dégi 2009 ) between 1.0-1.6 GPa and $800-1000{ }^{\circ} \mathrm{C}$. The only measured primary fluid inclusion in the wall rock of the Sab38 granulite shows that a $\mathrm{CO}_{2}-\mathrm{CO}$ fluid occasionally with traces of $\mathrm{H}_{2} \mathrm{~S}$ was present at the time of formation of the garnet-bearing granulite assemblage. This fluid composition is similar to that of previously published primary fluids in the lower crustal granulite xenoliths (Török et al. 2005).

\subsection{Fluid-rock interaction}

The clinopyroxene-plagioclase vein in the Sab38 xenolith texturally clearly overprints the original garnet granulite mineral assemblage and does not contain any garnet. Ilmenite-clinopyroxene \pm plagioclase intergrowths in the close vicinity of the vein show the reaction of melt and the accessory sphene in the granulitic wall-rock. Texturally two different generations of plagioclase can be found in the vein (Fig.2b). The textural relationship between SMI-bearing and the SMI-free plagioclases clearly shows relic nature of the latter ones in the vein (Fig.2b). This indicates that the SMI-bearing plagioclases are the products of fluid-rock interaction, while SMIfree plagioclases are relics of the former granulitic mineral assemblage (Fig.2b). 

Mi26 xenolith. The lack of garnet in the SMI-bearing clinopyroxene-plagioclase-rich domains and embayed relics of garnet around them (Fig.2c, 2d) would show that garnet was rather consumed than growing during fluid-rock interaction. These features suggest that the fluid-rock interaction, during which the new plagioclase and clinopyroxene and the enclosed fluid and melt inclusions formed, occurred at lower pressures than the granulite formation, out of the garnet stability field (Fig.5). This pressure decrease is also shown by the breakdown of garnets in the studied xenoliths (Fig.2c, d). Breakdown of the garnet is a widespread, pressure decrease induced reaction in the garnet granulite xenoliths found in the BBHVF (e.g. Török et al. 2005; Dégi et al. 2010) (Fig.5).

The plagioclases and the clinopyroxenes have differences in chemistry depending on their SMI-content and on their textural position. The most anorthitic plagioclase was found in the domains of sphene + melt reaction where ilmenite, clinopyroxene and plagioclase were formed. These domains are frequent close to the clinopyroxene-plagioclase vein in the Sab38 xenolith or near the clinopyroxene-plagioclase patches in Mi26 xenolith. The textural position of this reaction shows that limited amount of melt infiltrated to the host granulite. The relative anortite rich composition of the plagioclases was facilitated by the excess Ca from the breakdown of sphene and the decreasing pressure shown by the contemporaneous breakdown reaction of garnet (Johannes and Koepke 2001). Plagioclase compositions are more albitic in the newly formed clinopyroxene-plagioclase vein and in the clinopyroxene-plagioclase patches (Table 2) because the availability of $\mathrm{Na}$ in the percolating trachydacitic-dacitic-rhyolitic melt.

The pyroxenes also have differences in their major element contents depending on their textural position. In Sab38 xenolith, the clinopyroxene in the wall-rock contain higher amounts of $\mathrm{Al}_{2} \mathrm{O}_{3}$ than in the vein (Table 2). It is known, that the pyroxenes contain more Ca-tschermak component with the increasing pressure (e.g. Newton et al. 1977). This also suggests the fluid-rock interaction occurred at lower pressures than the formation of garnet granulites (Fig.5).

The fluids remain essentially $\mathrm{CO}_{2}$ dominated during the fluid-rock interaction, however there are spatial and temporal changes in the overall fluid composition. First of all we could observe differences in the composition of fluid inclusions and bubbles in the SMI of the different host minerals. The clinopyroxene-hosted fluids mostly consist of $\mathrm{CO}_{2}+\mathrm{H}_{2} \mathrm{O}$ in both FI and the bubbles of the SMI. The plagioclase-hosted FIs contain other gases in small quantity, such as $\mathrm{CO}, \mathrm{N}_{2}, \mathrm{H}_{2} \mathrm{~S}$ or $\mathrm{CH}_{4}$ (Table 3). This indicates that the pyroxene and plagioclase crystallised at different times in the presence of somewhat different fluids. Most probably the clinopyroxene crystallised first, because of its higher melting temperature. The slight changes in fluid composition may be due to change in composition of the percolating fluid in time and/or due to the fluid-rock interaction.

The composition of minor components in the fluid changes not just in time but also in space. $\mathrm{H}_{2} \mathrm{~S}$ is present in the fluids at Sabar Hill, whereas $\mathrm{N}_{2}$ is present in Mindszentkálla. The difference in the chemical compositions of the fluid between the same host minerals from different locations shows that the migrated fluids in the deep crust under the BBHVF were slightly heterogeneous. There were independent migration paths represented by clinopyroxene-plagioclase veins and domains with reaction microtextures (e.g. clinopyroxeneilmenite intergrowth, embayed grain boundaries) affected by fluid events.

The coexistence of the $\mathrm{CO}_{2}$-dominated primary FI (Table 3) together with the type $\mathrm{G}$ and type V primary SMI in plagioclase (Table 3) and also the variable bubble/melt ratio in the SMI shows that the two phases, one enriched in the volatile component and the other enriched in the silicate melt component, were trapped together from an inhomogeneous melt-fluid system (Fig.3a, b). The separation of the volatile-bearing phase from the silicate melt dominated part (present as FI) suggests that the silicate melt was saturated with the $\mathrm{CO}_{2}$-dominated volatile at the pressure and temperature of the formation of the plagioclase. This association suggests that immiscibility occurred between a silicate melt and a C-O-H-S-N volatile phase (i.e. FI) before or simultaneously with the formation of the plagioclase.

\subsection{P constraints of fluid-rock interaction.}

The upper pressure limit of the fluid-rock interaction is given by the lack of garnet in the new mineral assemblages (Fig.2a, b; Fig.5) and the widespread breakdown of garnet found around the newly formed domains or vein in the xenoliths (Fig.2d, Fig.5). The lower pressure limit of the fluid-rock interaction is given by the lack of the olivine in the newly formed domains (Fig.5). The present-day thickness of the lower (18-20 km) and upper crust $(10-12 \mathrm{~km})$ is known from geophysical measurements (Mituch and Posgay 1972; Posgay et al. 1991). The maximum depth is inferred from garnet breakdown at about $30 \mathrm{~km}$ (Török et al. 2005; Dégi et al. 2010), which is the base of the present-day crust where the stable mineral assemblage of the mafic granulites is clinopyroxene-orthopyroxene-plagioclase. The lower crust now extends upwards into the stability field of the olivine-plagioclase assemblage, because the present-day boundary between the lower and upper crust under the BBHVF is determined to be at about $12 \mathrm{~km}$ depth by Mituch and Posgay (1972) and Szafián et al. (1999). Thus, the above described fluid-rock reactions took place in the depths of the present day lower crust in the stability 
field of the pyroxene granulites between $0.6-0.8 \mathrm{GPa}$ with a final result of recrystallized clinopyroxeneplagioclase pockets and veins. This means that fluid-rock interactions may have happened at the final stages of the uplift of the lower crust when the garnet was not stable any more. Thinning of the crust and the stretching together imply the appearance of cracks, which can be the pathways for the generated melt and fluid which precipitated from the fluid-saturated melt. The clinopyroxene-plagioclase vein in Sab-38 xenolith represents a fluid and melt conduit, where intense interaction took place between the rock and the fluids. The Mi26 xenolith shows a different kind of fluid-rock interaction, where the relics are frequent and the new minerals formed only in patches (Fig.2d). These patches were formed by fluid and silicate melt inclusion-bearing clinopyroxene and plagioclase and represent the places of most intense fluid-rock interaction.

\subsection{Uplift of the xenoliths}

The last reaction we could observe is the uplift of the xenoliths in the basalt which means a high temperature interaction between the basalt and the samples (Fig.5). The irregular boundary and the decrepitation halo made up by lots of tiny inclusions around most of the SMI suggest decrepitation during the uplift in the basaltic magma. The chemical homogeneity and the lack of daughter minerals in most of the SMI indicate remelting and quenching of the SMI which are now consist of glass \pm bubble. (Fig.3b).

\section{5 'Water' content}

The bulk 'water' content of the equilibrium granulite assemblage is low (Table 4). Garnet is the main contributor to the low 'water' content of the whole rock as it does not contain FTIR-detectable 'water'. However 'water' contents of inclusion free clinopyroxenes (29-271 ppm wt. \%) and plagioclase (0-240 ppm wt. \%) are also low; Table 4) in comparison with eastern and northern Chinese granulites (200 - 2360 ppm wt. \% for clinopyroxene and 65-880 ppm wt. \% for plagioclase) (Xia et al. 2006; Yang et al. 2008), which are the only available data for comparison. The 'water' content in the orthopyroxene from the BBHVF is 189 - 193 ppm wt. $\%$, which is also lower compared to the Chinese granulite xenoliths 'water' content, between 130 to $1170 \mathrm{ppm}$ wt. $\%$.

The average structurally bound 'water' calculated from IR measurements shows $55 \pm 17$ ppm wt. \% 'water' in the wall rock part of the Sab38 sample and $77 \pm 23$ ppm wt. \% 'water' in the SMI free garnet granulitic domains of the Mi26 sample (Table 4). The average structurally bound 'water' content in the studied mafic garnet granulite samples from the BBHVF (Table 4) is less or coincides with the lowest values of the 65 - 900 ppm wt. \% interval calculated for the Chinese granulites (Xia et al. 2006; Yang et al. 2008). We can also show the dry nature of the studied lower crustal granulite xenoliths if we compare them with 'water' content measurements and calculations of the upper mantle peridotites under the BBHVF. The average bulk 'water' content in mantle xenoliths from the BBHVF presented by Kovács et al. (2013) is $\sim 40 \pm 12$ ppm wt. \% in amphibole-free peridotites (changes between 1-170 ppm wt. \%), which is very similar to those determined for the lower crustal granulites of the same locality. Similar conclusion can be drawn from a comparison of our data with the available published bulk 'water' content data of upper-mantle xenoliths, which is around 25-174 ppm wt. \% (Grant et al. 2007; Li et al. 2008).

The clinopyroxene-plagioclase vein in the Sab38 xenolith contains two different generations of plagioclase (Fig.2b), the SMI-bearing and the SMI-free plagioclase. The 'water' content and the distribution of 'water' in the two plagioclase generations are also in accordance with their different origin. The uniformly low 'water' content of the SMI-free relic plagioclase in the vein $(12 \pm 4 \mathrm{ppm}$ wt. \%) is similar to that of the plagioclase in the host rock ( $33 \pm 10 \mathrm{ppm}$ wt. \% 'water'). This may serve as an additional evidence for their relic nature. SMI-bearing plagioclases have a distinct zoning in 'water' content from a very low 'water' content on the SMI-free edge of the grain (0-19 ppm wt. \%) to the relatively high values in the vicinity of SMI (up to $684 \mathrm{ppm}$ wt. \%) in the internal parts of the grain (Fig.4, Table 4). The elevated 'water' content near the SMI may show the elevated 'water' content of the crystallizing melt and the diffusion of 'water' out of the melt inclusions. An interesting question is the contribution of V type SMI to the 'water' content of the host plagioclase. We were not able to detect any volatile species in the type V SMIs either by microthermometry or Raman spectroscopy. The dark appearance and the big size and other textural features indicate that these SMI might have been fluid-rich melt inclusions, which decrepitated during uplift of the xenoliths. IR profiles show 'water' enrichment in the close vicinity of these inclusions, thus it is plausible to assume that 'water' was present in these inclusions.

Interestingly the 'water' content of the SMI-bearing clinopyroxenes (max. 227 ppm wt. \%) does not differ very much from those without SMI (max. 271 ppm wt. \%, Table 4). This may be caused by lower 'water' concentration gradient between the SMIs and the hosting clinopyroxenes. The elevated 'water' content in plagioclase around SMI clusters may be due to higher 'water' concentration gradient and/or faster diffusion of 'water' out of the inclusions. An additional cause may be the much smaller number of FI and SMI in the clinopyroxenes than in the plagioclase. The explanation of this difference between plagioclase and clinopyroxene in the behaviour of water in the vicinity of inclusions are hampered by the fact that there are only very limited data available in the literature on 'water' content of granulites (Xia et al. 2006; Yang et al. 2008). In 
addition, diffusion and partition coefficients of hydrogen in plagioclase and clinopyroxene under these conditions have not yet been precisely constrained.

Using the average modal compositions (Chapter 4.1), the total structurally bound 'water' content of the SMIbearing clinopyroxene-plagioclase rich parts of the Mi26 xenolith is $413 \pm 124 \mathrm{ppm}$ wt. \% which is much higher than that of the garnet-bearing SMI-free parts $(77 \pm 23 \mathrm{ppm} w \mathrm{w} . \%)$. Also in Sab38 the plagioclase-clinopyroxene vein of the sample contains higher amounts of 'water' $(390 \pm 117 \mathrm{ppm}$ wt. \%), than the wall-rock part $(55 \pm 17$ ppm wt. \%). This implies, that the originally dry garnet bearing mafic granulite was partially 'hydrated' by fluidrich melts during fluid-rock interactions.

\section{Conclusions}

A large number of lower crustal mafic garnet granulite xenoliths were found and studied in the BBHVF but only two samples (Mi26 and Sab38) contain primary SMI, hosted by the rock forming plagioclase, clinopyroxene and ilmenite. The primary, equilibrium mineral assemblage of mafic garnet granulites shows $\mathrm{p}-\mathrm{T}$ conditions comparable with those studied previously. According to Raman and IR spectroscopy, this mineral assemblage is dry and contains $\mathrm{CO}_{2}$-dominated $\pm \mathrm{CO}, \mathrm{H}_{2} \mathrm{~S}$ fluid inclusions.

The original garnet granulitic mineralogy is overprinted by primary silicate melt inclusion-bearing plagioclase, clinopyroxene and ilmenite. This assemblage has higher 'water' content indicating local hydration of the originally dry lower crust. Textural features suggest that garnet was consumed during the fluid-rock interaction, which shows that these reactions were active in the final stages of the uplift of the lower crust when the low pressure conditions induced the breakdown of garnet.

The composition of fluids changed during the fluid-rock interaction. The first fluid, which was present during the formation of the clinopyroxenes had a simple composition of $\mathrm{CO}_{2}+\mathrm{H}_{2} \mathrm{O}$. The crystallisation of plagioclase took place in a more complex heterogeneous fluid-melt system forming vapour rich and glass rich SMI. The chemical composition of the $\mathrm{CO}_{2}+\mathrm{H}_{2} \mathrm{O}$ fluid became more complex with the addition of $\mathrm{N}_{2}$ and $\mathrm{CH}_{4}$.

\section{Acknowledgements}

We would like to thank for the financial support of OTKA NN 79943 to K. Török, and for the support of REG_KM_INFRA_09 Gábor Baross Programme which made possible the Raman analyses. I.K greatly acknowledges the support of MC IRG (NAMs-230937) and OTKA PD101683 grants for the IR analyses. This is the publication N 72 of the LRG, ELTE in collaboration with MFGI. The authors acknowledge the critical comments of the two anonymous referees, which helped us to improve the early version of the manuscript.

\section{References}

Ai Y (1994) A revision of the garnet-clinopyroxene $\mathrm{Fe}^{2+}-\mathrm{Mg}$ exchange geothermometer. Contrib Mineral Petrol 115:467-473.

Balogh K, Árva-Sós E, Pécskay Z, Ravasz-Baranyai L (1986) K/Ar dating of Post-Sarmatian alkali basaltic rocks in Hungary. Acta Miner-Petr 28:75-84.

Balogh K, Lobitzer H, Pécskay Z, Ravasz Cs (1990) K/Ar date of tertiary alkaline basalts from Burgenland and Eastern-Styrian Basin. Annual report of the Hungarian Geological Survey from the year of $1988.1^{\text {st }}$ part 451-X./ 0.000( 0) (in Hungarian)

Bell DR, Ihinger PD, Rossmann GR (1995) Quantitative-analysis of trace OH in garnet and pyroxenes. American Mineralogist 80 (5-6):465-474.

Berkesi M, Hidas K, Guzmics T, Dubessy J, Bodnar RJ, Szabó Cs, Vajna B, Tsunogae T (2009) Detection of small amounts of $\mathrm{H}_{2} \mathrm{O}$ in $\mathrm{CO}_{2}$-rich fluid inclusions using Raman spectroscopy. Journal of Raman Spectroscopy 40:1461-1463.

Csontos L, Vörös A (2004) Mesozoic plate tectonic reconstruction of the Carpathian region. Palaeogeography, Palaeoclimatology, Palaeoecology 210 (1):1-56.

Dégi J (2009) Detailed Study of Mafic Lower Crustal Xenoliths From The Bakony-Balaton Highland Volcanic Field; Relationships Between Metamorphic Processes in The Lower Crust and The Formation of The Pannonian Basin. unpubl. PhD Thesis, Eötvös University

Dégi J, Abart R, Török K, Rhede D, Petrischeva E (2009) Evidence for xenolith - host basalt interaction from chemical patterns in Fe-Ti-oxides from mafic granulite xenoliths of the Bakony-Balaton Volcanic field (W-Hungary). Mineral Petrol 95 (3):219-234.

Dégi J, Abart R, Török K, Bali E, Wirth R, Rhede D (2010) Symplectite formation during decompression induced garnet breakdown in lower crustal mafic granulite xenoliths: mechanisms and rates. Contrib Mineral Petrol 159:293-314.

Dégi J, Török K (2003) Petrographic evidence of crustal thinning in Bakony-Balaton Highland Volcanic Field (in Hungarian). Magyar Geofizika 44 (4):125-133. 
Dobosi G, Kempton P, Downes H, Embey-Isztin A, Thirlwall M, Greenwood P (2003) Lower crustal xenoliths from the Pannonian Basin, Hungary. Part 2: Sr-Nd-Pb-Hf and $\mathrm{O}$ isotope evidence for formation of continental lower crust by tectonic emplacement of oceanic crust. Contrib. Mineral. Petrol. 144:671-683.

Dubessy J, Boiron MC, Moissette A, Monnin C, Sretenskaya N (1992) Determination of water, hydrates and $\mathrm{pH}$ in fluid inclusions by micro-Raman spectrometry. Eur JMineral 4:885-894.

Eckert JO Jr, Newton RC, Kleppa OJ (1991) The $\Delta \mathrm{H}$ of reaction and recalibration of garnet-pyroxeneplagioclase-quartz geobarometers in the CMAS system by solution calorimetry. Am Mineral 76:148-160.

Embey-Isztin A (1976) Amphibolite/lherzolite composite xenolith from Szigliget, north of the Lake Balaton, Hungary. Earth and Planetary Science Letters 31:297-304.

Embey-Isztin A, Downes H, Kempton P, Dobosi G, Thrilwall M (2003) Lower crustal xenoliths from the Pannonian Basin, Hungary. Part 1: mineral chemistry, thermobarometry and petrology. Contrib Mineral Petrol 144:652-670.

Embey-Isztin A, Sharbert HG, Dietrich H, Poultidis H (1990) Mafic granulites and clinopyroxenite xenoliths from the Transdanubian Volcanic Region (Hungary): implications for the deep structure of the Pannonian Basin. Mineral Mag 54:463-483.

Fodor L, Csontos L, Bada G, Győrfi I, Benkovics L (1999) Tertiary tectonic evolution of the Pannonian basin system and neighbouring orogens, a new synthesis of paleostress data, in: Durand B, Jolivet L, Horváth F, Séranne M (Eds.), The Mediterranean Basins: Tertiary extension within the Alpine Orogen. Geological Society, London, Special Publications 156:295-334.

Grant KJ, Brooker RA, Kohn SC, Wood BJ (2007) The effect of oxygen fugacity on hydroxyl concentrations and speciation in olivine: Implications for water solubility in the upper mantle.Earth and Planetary Science Letters 261:217-229.

Harangi Sz (2001) Neogene to Quartenary volcanism of the Carpatian-Pannonian Region. A review: Acta Geologica Hungarica 44:223-258.

Harangi Sz, Wilson M, Tonarini S (1995) Petrogenesis of Neogene potassic volcanic rocks in the Pannonian Basin. Acta Vulcanol 7:125-134.

Hidas K, Guzmics T, Szabó Cs, Kovács I, Bodnar RJ, Zajacz Z, Nédli Zs, Vaccari L, Perucchi A (2010) Coexisting silicate melt inclusions and $\mathrm{H}_{2} \mathrm{O}$-bearing, $\mathrm{CO}_{2}$-rich fluid inclusions in mantle peridotite xenoliths from the Carpathian-Pannonian region (central Hungary). Chemical Geology 274:1-18.

Horváth F, Bada G, Szafián P, Tari G, Ádám A, Cloetingh S (2006) Formation and deformation of the Pannonian basin: constraints from observational data. In: Gee DG, Stephenson RA (Eds.), European Lithosphere Dynamics. 32. Geological Society, London, pp 191-206.

Huismans RS, Podladchikov YY, Cloetingh S (2001) Dynamic modeling of the transition from passive to active rifting, application to the Pannonian basin. Tectonics 20:1021-1039.

Irving AJ (1974) Geochemical and high-pressure experimental studies of garnet pyroxenite and pyroxene granulite xenoliths from the Delegate Basaltic pipes, Australia. J Petrol 15:1-40.

Johannes W, Koepke J (2001) Incomplete reaction of plagioclase in experimental dehydration melting of amphibolite. AJES 48:581-590.

Johnson EA, Rossman GR (2003) The concentration and speciation of hydrogen in feldspars using FTIR and 1H MAS NMR spectroscopy. American Mineralogist 88:901-911.

Jugovics L (1968) Structure of the basalt regions in the Balaton Highland. Yearly Report of the Hungarian Geological Institute, pp 75-82. Hungarian Geological Institute, Budapest

Kázmér M, Kovács S (1985) Permian-Paleogene paleography along the eastern part of the Insubric-Periadriatic Lineament system: Evidence for continental escape of the Bakony-Drauzug Unit. Acta Geologica Hungarica 28:71-84.

Kempton P, Downes H, Embey-Isztin A (1997) Mafic granulite xenoliths in Neogene alkali basalts from the Western Pannonian Basin: insights into the lower crust of a collapsed orogen. Journal of Petrology 38:941-970.

Kovács I, Hermann J, O’Neill HSt.C, Fitz Gerald JD, Sambridge M, Horvath G (2008) Quantitative absorbance spectroscopy with unpolarized light, Part II: Experimental evaluation and development of a protocol for quantitative analysis of mineral IR spectra. American Mineralogist 93:765-778.

Kovács I, Green DH, Rosenthal A, Hermann J, O’Neill HSt.C, Hibberson WO, Udvardi B, (2012) An experimental study of water in nominally anhydrous minerals in the upper mantle near the water-saturated solidus. Journal of Petrology 53:2037-2093.

Kovács I, Falus Gy, Szabó Cs, Kiss J, Fancsik T, Hegedüs E, Pintér Zs, Liptai N, Patkó, L (2013) Integrated geological and geophysical probing of lithospheric dynamics in a young extensional basin (CarpathianPannonian Region). 23rd V. M. Goldschmidt Conference, August 25-30, 2013, Florence (Italy), USB flash drive (DOI:10.1180/minmag.2013.077.5.11)

Kovács I, Szabó Cs (2005) Geodynamical significance of granulite xenoliths beneath the Nógrád-Gömör Volcanic Field, Carpathian-Pannonian Region (N-Hungary/SSlovakia). MinPet 85:269-290. 
Kovács I, Szabó Cs (2008) Middle Miocene volcanism in the vicinity of the Middle Hungarian zone: Evidence for an inherited enriched mantle source. Journal of Geodynamics 45 (1):1-17.

Kretz R (1983) Symbols for rock-forming minerals. Am Mineral 68:277-279.

Kushiro I, Yoder HS (1966) Anorthite - forsterite and anorthite-enstatite reactions and their bearing on the basalt - eclogite transformation. Journal of Petrology 7:337-362.

Lexa J, Seghedi I, Németh K, Szakács A, Konečný V, Pécskay Z, Fülöp A, Kovacs M (2010) NeogeneQuaternary volcanic forms in the Carpathian-Pannonian Region: a review. Cent Eur J Geosci 2(3):207270.

Li ZXA, Lee CTA, Peslier AH, Lenardic A, Mackwell SJ (2008) Water contents in mantle xenoliths from the Colorado Plateau and vicinity: Implications for the mantle rheology and hydration-induced thinning of continental lithosphere, Journal Of Geophysical Research 113, B09210, DOI:10.1029/2007JB005540

Mituch E, Posgay K (1972) The crustal structure of Central and Southeastern Europe on the results of explosion seismology; Hungary. Geophys Transactions Spec Ed. Eötvös Loránd Geofizikai Intézet, Budapest, 118131.

Newton RC, Charlu TV, Kleppa OJ (1977) Thermochemistry of high pressure garnets and clinopyroxenes in the system CaO-MgO-Al2O3-SiO2. GCA 41:369-377.

Newton RC, Perkins DIII (1982) Thermodynamic calibration of geobarometers based on the assemblages garnetplagioclase-orthopyroxene (clinopyroxene)-quartz. American Mineralogist 67:203-222.

Németh B, Badenszki E, Koller F, Török K, Mogassie A, Szabó Cs (2009) Mid-crustal xenoliths from Beistein, Austria. EGU General Assembly. April 19-24, 2009, Vienna, Geophysical Research Abstracts 11, (EGU2009): 5618.

Németh B, Török K, Szabó Cs (2011) Fluid-rock Interactions in Mafic Granulite Xenoliths From Bakony Balaton Highland Volcanic Field, European Current Research on Fluid Inclusions (ECROFI-XXI) Augiust 8-11, 2011, Leoben, Austria, Programme and Abstracts, 150-151.

Panaiotu CG, Pécskay Z, Hambach U, Seghedi I, Panaiotu CE, Tetsumaru I, Orleanu M, Szakács A (2004) Short-lived Quaternary volcanism in the Per $\square$ sani Mountains (Romania) revealed by combined K-Ar and paleomagnetic data. Geol Carpathica 55 (4):333-339.

Posgay K, Albu I, Mayerova M, Nakladalova Z, Ibrmajer I, Blizkovski M, Aric K, Gutdeutsch R (1991) Contour map of the Mohorovicic discontinuity beneath Central Europe Geophys Trans 36:7-13.

Roedder E (1984) Fluid Inclusions. Review in Mineralogy 12:1-646.

Sambridge M, Fitz Gerald JD, Kovács I, O’Neill HSt.C, Hermann J (2008) Quantitative IR spectroscopy with unpolarized light, Part I: Physical and mathematical development. American Mineralogist 93:751-764.

Szafián P, Tari G, Horváth F, Cloetingh S (1999) Crustal structure of the Alpine-Pannonian transition zone: a combined seismic and gravity study. Int J Earth Sci 88:98-110.

Thomas SM, Koch-Müller M. Reichart P, Rhede D, Thomas R, Wirth R, Matsyuk S (2008) IR calibrations for water determination in olivine, $\mathrm{r}-\mathrm{GeO} 2$, and $\mathrm{SiO} 2$ polymorphs. Phys Chem Minerals 36:489-509.

Török K (1995) Garnet breakdown reaction and fluid inclusions in a garnet-clinopyroxenite xenolith from Szentbékkálla (Balaton-Highland, Western Hungary). Acta Vulcanol 7 (2):285-290.

Török K (2002) Ultrahigh-temperature metamorphism of a buchitised xenolith from the basaltic tuff of Szigliget (Hungary). Acta Geologica Hungarica 45:175-192.

Török K (2012) On the origin and fluid content of some rare crustal xenoliths and their bearing on the structure and evolution of the crust beneath the Bakony-Balaton Highland Volcanic Field (W-Hungary) Int J Earth Sci (Geol. Rundsch) 101:1581-1597.

Török K, Dégi J, Marosi Gy, Szép A (2005) Reduced carbonic fluids in mafic granulite xenoliths from the Bakony-Balaton Highland Volcanic Field, W-Hungary. Chemical Geology 223:93-108.

Török K, Dégi J, Marosi Gy (2007) High temperature melting of biotite in CO2 rich environment and formation of orthopyroxene-garnet-plagioclase rocks in the lower crust: A xenolith example from the BakonyBalaton Highland Volcanic Field (W-Hungary). European Current Research on Fluid Inclusions XIX. 1720 July 2007, Bern, Abstract Volume, 242.

Török K, Németh B, Koller F, Dégi J, Badenszki E, Szabó Cs, Mogessie A (2014) Evolution of the middle crust beneath the western Pannonian Basin: a xenolith study. Mineralogy and Petrology 108:33-47.

Xia QK, Yang XZ, Deloule E, Sheng YM, Hao YT (2006) Water in the lower crustal granulite xenoliths from Nushan, eastern China. Journal of Geophysical Research, 111 (B11202) DOI:10.1029/2006JB004296.

Yang XZ, Xia QK, Deloule E, Dallai L, Fan QC, Fend M (2008) Water in minerals of the continental lithospheric mantle and overlying lower crust: A comparative study of peridotite and granulite xenoliths from the North China Craton. Chemical Geology 256 (1-2):33-45.

Figure captions 
Fig.1a Map of the Pannonian Basin with the main tectonic units (ALCAPA and Tisza-Dacia separated by the Middle Hungarian Zone (MHZ) after Csontos and Vörös 2004; Hidas et al. 2010; and references therein). Position of the Bakony-Balaton Highland Volcanic Field (BBHVF) is shown for orientation. Satellite image is downloaded from Google Earth. HUN: Hungary; UA: Ukraine; RO: Romania; SRB: Serbia; BIH: Bosnia and Herzegovina; HR: Croatia; SLO: Slovenia; A: Austria; CZ: Czech Republic; PL: Poland; SK: Slovakia.

Fig.1b Schematic map of the Bakony-Balaton Highland Volcanic Field (BBHVF) with the locations of the studied lower crustal xenoliths, Mindszentkálla (Mi26) and Sabar-hegy near Káptalantóti (Sab38). The map is modified after Jugovics (1968) and Harangi (2001)

Fig.2a Scanned thin section of xenolith Sab38. The dashed area shows the clinopyroxene-plagioclase vein, which contain coexisting primary silicate melt and fluid inclusions. Fig.2b Sketch map of the microtexture of the Pl-Cpx vein. Note the significantly different appearance of SMI-free and SMI-bearing plagioclase grains. Fig.2c Microphotograph of the non-eqilibrium microtexture of xenolith Mi26. In most cases garnets were replaced by symplectites, and form embayed, loop-like pseudomorphs. There are some equilibrium domains in the microtexture, which is formed by Cpx and Grt. In this case, the grain boundary of the Grt and the Cpx is straight. Fig.2d SMI-bearing plagioclase and cinopyroxene grains surrounded by SMI-free plagioclases and minerals. Note, that garnet relics were observed only in the SMI-free mineral assemblage. Mineral abbreviations follow Kretz (1983)

Fig.3a Microphotograph of the primary silicate melt inclusions (SMI) in plagioclase (Pl) and clinopyroxene (Cpx) host minerals. Fig.3b Microphotograph of type V and type G SMI in Pl host mineral. Fig.3c Microphotograph of primary SMI in Cpx host mineral. Decrepitation halo is observed around the SMI, which consist of brown glass and a two-phased bubble at room temperature. According to microthermometry and Raman analyses, the bubble consists of liquid and vapour phase of $\mathrm{CO}_{2}$. Fig.3d Microphotograph of primary SMI in ilmenite (Ilm) host mineral. It contains glass, bubble, and an accidentally trapped apatite (Ap) crystal. Mineral abbreviations follow Kretz (1983)

Fig.4 Representative profiles across plagioclases, which were chosen from 12 profiles (111 point analyses).

Fig.4a microphotograph of the measurement points of an SMI-bearing plagioclase in xenoolith Mi26.

Abbreviations: pt - points of analyses, SMI - silicate melt inclusion. Fig.4b diagram of the 'water' content in the measured points from picture A. The diagram shows the integrated area of each point, but the 'water' content in ppm wt. \% is also indicated above the corresponding points. Fig.4c microphotograph of the measurement points of an SMI-bearing plagioclase in xenolith Mi26. Fig.4d diagram of the 'water' content in the measured points from picture $\mathrm{C}$. The diagram shows the integrated area of each point, but the 'water' content in ppm wt. \% is also indicated above the corresponding point. In point 2, where type G SMI were analysed, the 'water' content increases in smaller rate than in point 3, where type G and V SMIs were analysed together, or than in point 4, which is a type V SMI. Mineral abbreviations follow Kretz (1983)

Fig.5 Pressure-temperature-depth diagram with the known steps of the granulite's evolution beneath the western Pannonian Basin. The box show the equilibrium pressure and temperature range of the mafic garnet granulites from BBHVF by previously published data on the P-T evolution of garnet granulites (Török et al. 2005). 1 upper stability of Fo + An assemblage (Kushiro and Yoder 1966). 2 lower stability limit of garnet in mafic compositions (Irving 1974). The dotted arrow shows the pressure decrease for mafic garnet granulite. Line M represents the present-day Moho, according to (Posgay et al. 1991). Line L represents the depth of the presentday lower crust, according to Mituch and Posgay (1972) and Szafián et al. (1999). Simplified figure after Dégi (2009) and Török (2012). The thick dashed arrow shows the upwelling with the alkaline basalt. The thin dashed arrows show the upwelling of the xenoliths. 


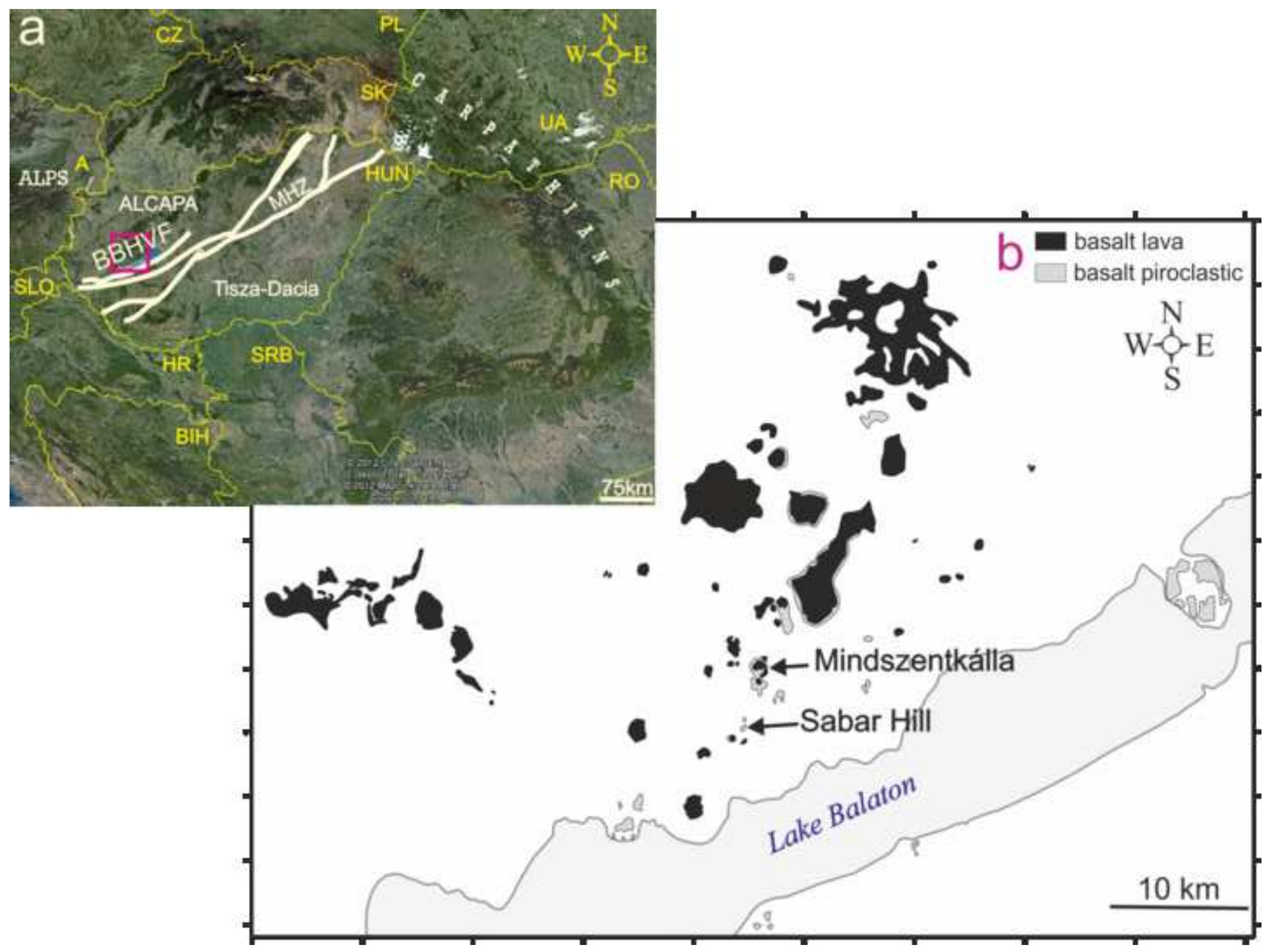



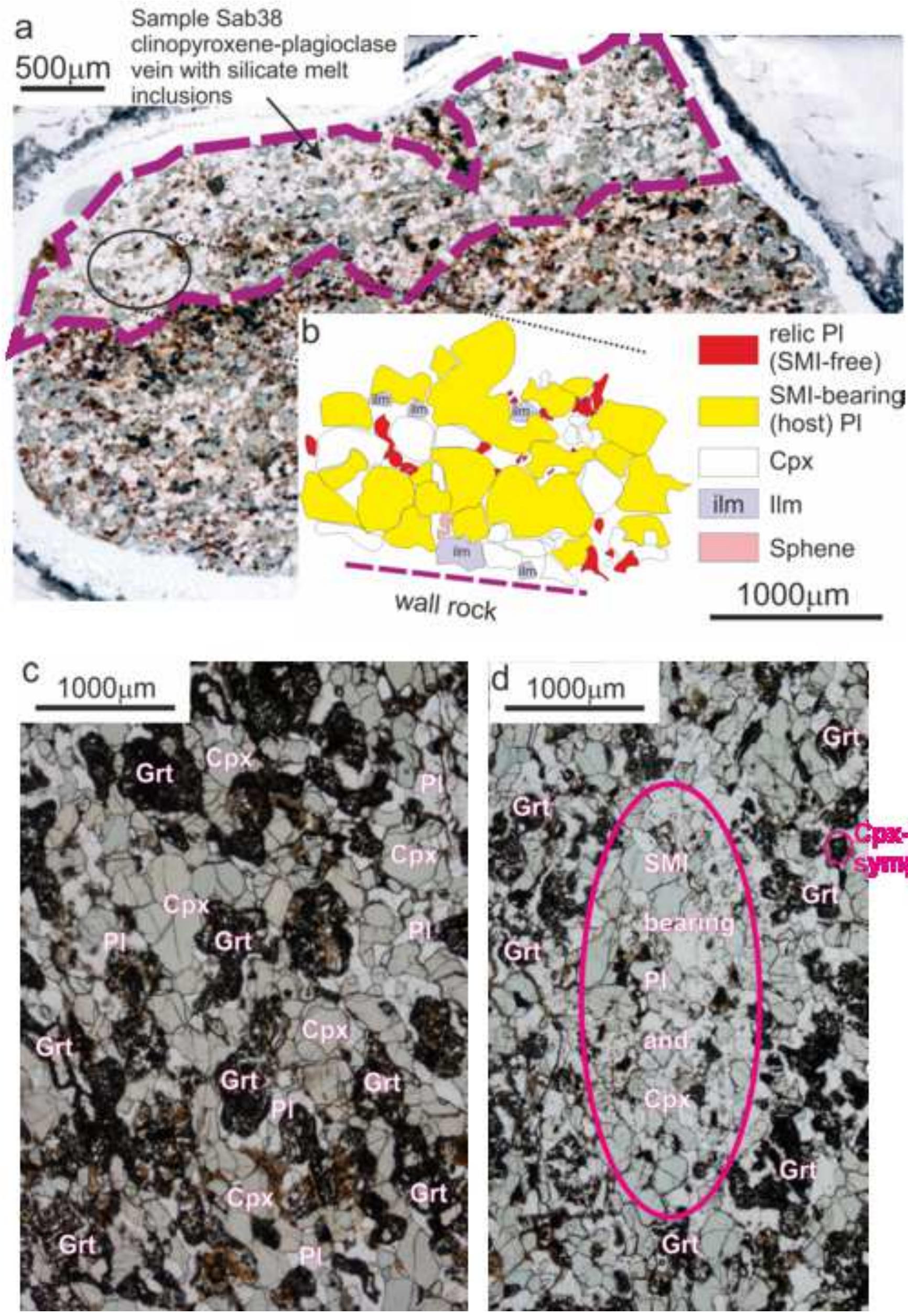

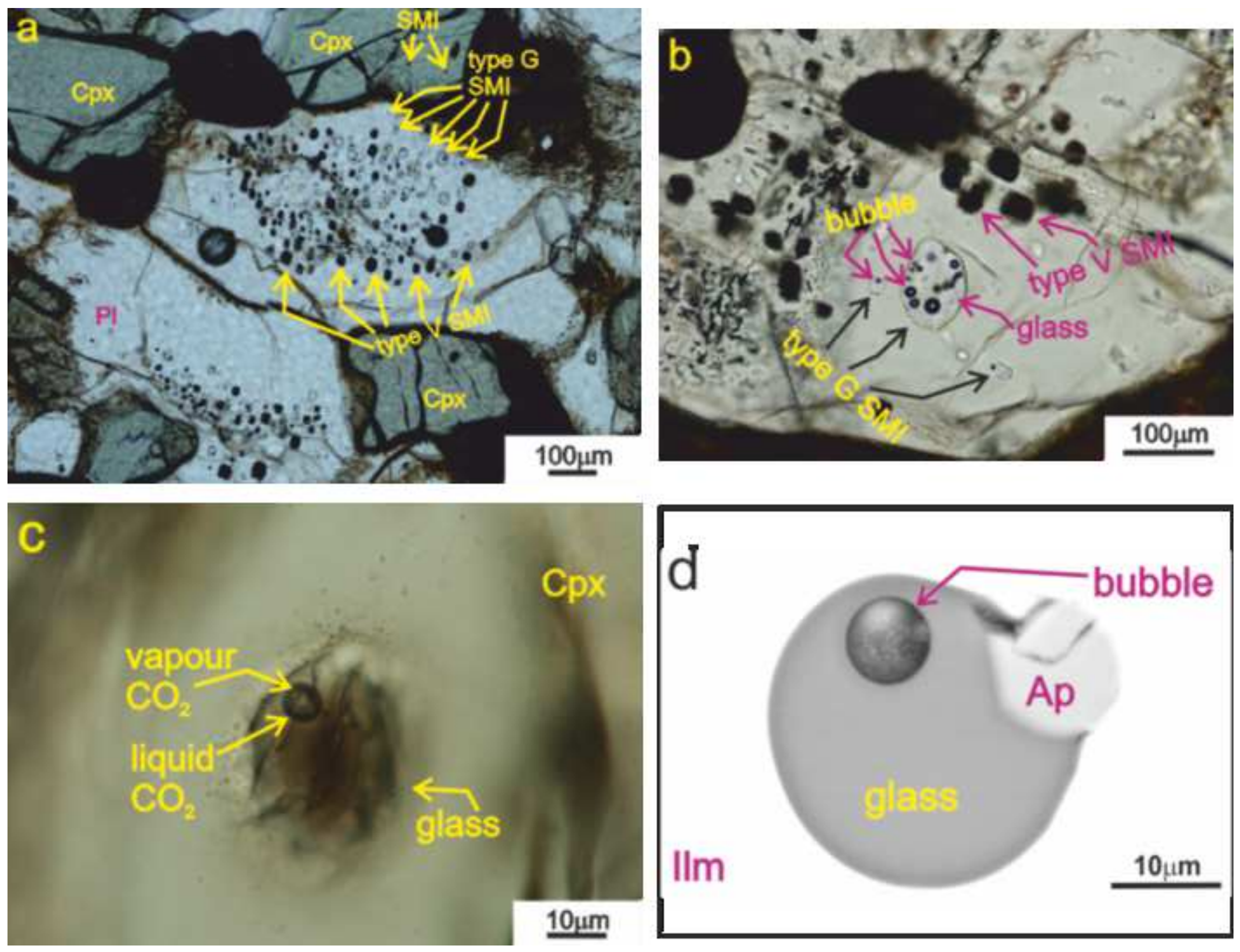


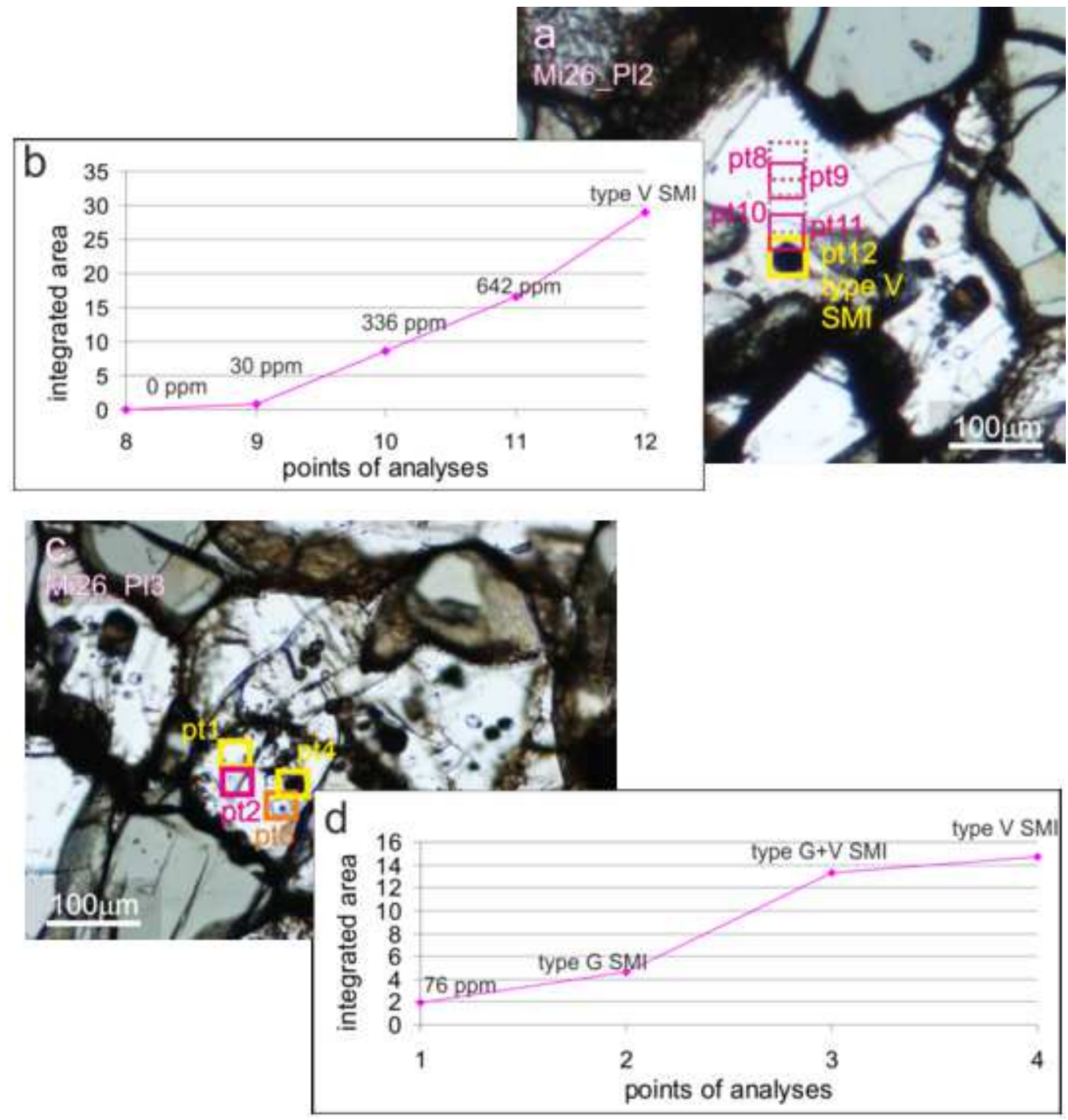



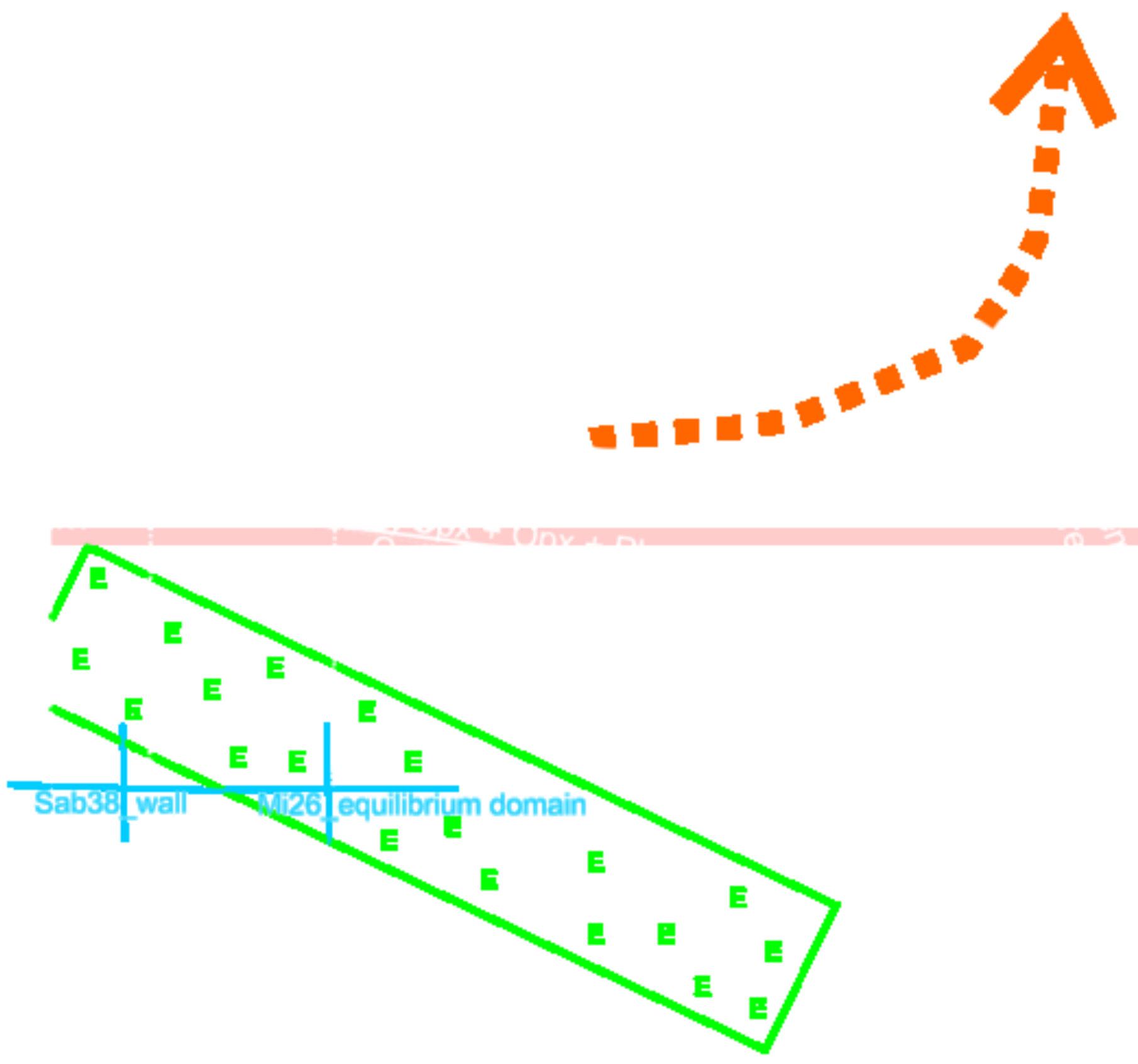
Table 1 Occurrence of primary fluid inclusions $(\mathrm{FI})$ and the silicate melt inclusions (SMI) in the studied xenoliths. Mineral abbreviations after Kretz (1983)

\begin{tabular}{|c|c|c|c|c|c|}
\hline type & occurrence & & & sample & \\
\hline \multirow{5}{*}{$\mathrm{FI}$} & & & Sab38wall & Sab38vein & Mi26 \\
\hline & $\begin{array}{l}\text { without the presence of SMI } \\
\text { (type I) }\end{array}$ & primary & - & $\mathrm{PI}$ & Cpx \\
\hline & (type III) & primary & $\mathrm{PI}$ & - & - \\
\hline & in the presence of SMI & & & & \\
\hline & (type II) & primary & - & $\mathrm{PI}, \mathrm{Cpx}$ & $\mathrm{Pl}$ \\
\hline \multirow{2}{*}{ SMI } & type G & primary & - & $\mathrm{PI}, \mathrm{Cpx}, \mathrm{Ilm}$ & $\mathrm{PI}, \mathrm{Cpx}, \mathrm{IIm}$ \\
\hline & type $\mathrm{V}$ & primary & - & PI & PI \\
\hline
\end{tabular}




\begin{tabular}{|c|c|c|c|c|c|c|c|c|c|c|}
\hline \multirow{2}{*}{$\begin{array}{c}\text { Plagioclase } \\
\# \text { analyses }\end{array}$} & \multicolumn{3}{|c|}{ Mi26 } & \multicolumn{2}{|c|}{ Sab38 vein } & \multicolumn{2}{|c|}{ Sab38 wall rock } & \multirow{2}{*}{$\begin{array}{l}\text { Garnet } \\
\text { \# analyses }\end{array}$} & \multirow{2}{*}{$\begin{array}{c}\text { Mi26 } \\
\text { Grt-Cpx-PI }\end{array}$} & \multirow{2}{*}{$\begin{array}{l}\text { Sab38_wall rock } \\
\text { Grt-Cpx-PI }\end{array}$} \\
\hline & SMI containing & SMI-free & Cpx-IIm sympl & SMI containing & SMI-free & as inclusion in Cpx & Cpx-IIm sympl & & & \\
\hline $\mathrm{SiO}_{2}$ & 57.40 & 54.47 & 56.50 & 61.21 & 61.34 & 56.05 & 57.13 & $\mathrm{SiO}_{2}$ & 38.59 & 39.37 \\
\hline $\mathrm{Al}_{2} \mathrm{O}_{3}$ & 26.73 & 28.34 & 27.55 & 24.08 & 24.13 & 27.32 & 27.27 & $\mathrm{TiO}_{2}$ & 0.00 & 0.00 \\
\hline $\mathrm{FeO}$ tot & 0.16 & 0.33 & 0.30 & 0.17 & 0.00 & 0.00 & 0.00 & $\mathrm{Al}_{2} \mathrm{O}_{3}$ & 21.32 & 22.01 \\
\hline $\mathrm{CaO}$ & 8.94 & 10.930 & 9.74 & 5.95 & 5.75 & 9.46 & 9.39 & $\mathrm{FeO}$ tot & 27.44 & 23.17 \\
\hline $\mathrm{Na}_{2} \mathrm{O}$ & 6.09 & 5.39 & 5.58 & 7.75 & 7.51 & 6.14 & 6.20 & $\mathrm{MnO}$ & 0.54 & 1.16 \\
\hline $\mathrm{K}_{2} \mathrm{O}$ & 0.62 & 0.54 & 0.55 & 0.94 & 1.26 & 0.31 & 0.62 & $\mathrm{MgO}$ & 5.59 & 7.48 \\
\hline$\Sigma$ & 99.93 & 100.00 & 100.22 & 100.14 & 99.99 & 99.27 & 100.61 & $\mathrm{CaO}$ & 7.75 & 6.74 \\
\hline Si & 2.58 & 2.47 & 2.54 & 2.73 & 2.73 & 2.54 & 2.55 & $\Sigma$ & 101.23 & 99.94 \\
\hline Al & 1.42 & 1.51 & 1.46 & 1.26 & 1.27 & 1.46 & 1.44 & $\mathrm{Si}$ & 2.97 & 3.02 \\
\hline $\mathrm{Fe}$ & 0.01 & 0.01 & 0.01 & 0.01 & 0.00 & 0.00 & 0.00 & $T i$ & 0.00 & 0.00 \\
\hline $\mathrm{Ca}$ & 0.43 & 0.53 & 0.47 & 0.28 & 0.27 & 0.46 & 0.45 & Al & 1.93 & 1.99 \\
\hline $\mathrm{Na}$ & 0.53 & 0.47 & 0.49 & 0.67 & 0.65 & 0.54 & 0.54 & $\mathrm{Fe}$ & 1.76 & 1.49 \\
\hline K & 0.04 & 0.03 & 0.03 & 0.05 & 0.07 & 0.02 & 0.04 & $M n$ & 0.04 & 0.08 \\
\hline$\Sigma$ & 5.00 & 5.03 & 4.99 & 5.00 & 4.99 & 5.01 & 5.01 & $M g$ & 0.64 & 0.86 \\
\hline$A b$ & 53.25 & 45.74 & 49.28 & 66.49 & 65.21 & 53.06 & 52.43 & $\mathrm{Ca}$ & 0.64 & 0.55 \\
\hline$A n$ & 43.20 & 51.25 & 47.53 & 28.23 & 27.59 & 45.18 & 43.69 & $\Sigma$ & 7.97 & 7.98 \\
\hline Or & 3.55 & 3.01 & 3.20 & 5.28 & 7.20 & 1.76 & 3.88 & Py & 20.81 & 28.79 \\
\hline Pyroxenes & Mi26 & & Sab38 & 8_vein & Sab38_wall roc & & & $A / m$ & 57.31 & 50.03 \\
\hline \# analyses & SMI containing & SMI-free & SMI containing & SMI-free & Cpx-IIm sympl & Opx & & Gro & 20.74 & 18.64 \\
\hline $\mathrm{SiO}_{2}$ & 51.17 & 50.52 & 51.35 & 50.63 & 49.27 & 50.07 & & Sps & 1.14 & 2.54 \\
\hline
\end{tabular}

\begin{tabular}{|c|c|c|c|c|c|c|}
\hline $\mathrm{TiO}_{2}$ & 0.29 & 0.54 & 0.26 & 0.33 & 0.48 & 0.16 \\
\hline $\mathrm{Al}_{2} \mathrm{O}_{3}$ & 2.22 & 3.55 & 1.92 & 3.27 & 4.54 & 3.04 \\
\hline $\mathrm{Cr}_{2} \mathrm{O}_{3}$ & 0.08 & 0.00 & 0.02 & 0.00 & 0.00 & 0.00 \\
\hline $\mathrm{FeO}$ tot & 13.28 & 12.93 & 14.63 & 12.04 & 13.95 & 27.56 \\
\hline $\mathrm{MnO}$ & 0.19 & 0.00 & 0.45 & 0.00 & 0.27 & 0.63 \\
\hline $\mathrm{NiO}$ & 0.00 & 0.00 & 0.00 & 0.00 & 0.00 & 0.00 \\
\hline $\mathrm{MgO}$ & 11.62 & 11.17 & 11.02 & 12.06 & 11.49 & 17.62 \\
\hline $\mathrm{CaO}$ & 20.32 & 21.3 & 19.53 & 21.65 & 19.50 & 1.17 \\
\hline $\mathrm{Na}_{2} \mathrm{O}$ & 0.44 & na & 0.53 & 0.00 & 0.40 & 0.00 \\
\hline$\Sigma$ & 99.63 & 100.01 & 99.71 & 100.00 & 100.01 & 100.25 \\
\hline Si & 1.94 & 1.92 & 1.96 & 1.91 & 1.88 & 1.91 \\
\hline Ti & 0.01 & 0.02 & 0.01 & 0.01 & 0.01 & 0.00 \\
\hline Al & 0.10 & 0.16 & 0.09 & 0.15 & 0.20 & 0.14 \\
\hline $\mathrm{Cr}$ & 0.00 & 0.00 & 0.00 & 0.00 & 0.00 & 0.00 \\
\hline $\mathrm{Fe}$ & 0.42 & 0.41 & 0.47 & 0.38 & 0.44 & 0.88 \\
\hline$M n$ & 0.01 & 0.00 & 0.01 & 0.00 & 0.01 & 0.02 \\
\hline $\mathrm{Ni}$ & 0.00 & 0.00 & 0.00 & 0.00 & 0.00 & 0.00 \\
\hline$M g$ & 0.66 & 0.63 & 0.63 & 0.68 & 0.65 & 1.00 \\
\hline $\mathrm{Ca}$ & 0.83 & 0.87 & 0.80 & 0.04 & 0.79 & 0.05 \\
\hline $\mathrm{Na}$ & 0.03 & 0.00 & 0.04 & 0.88 & 0.03 & 0.00 \\
\hline$\Sigma$ & 4.00 & 4.00 & 4.01 & 4.00 & 4.03 & 4.00 \\
\hline En & 34.39 & 33.11 & 32.88 & 35.08 & 36.30 & 51.40 \\
\hline Fs & 22.37 & 21.50 & 25.25 & 19.65 & 19.58 & 46.15 \\
\hline Wo & 43.23 & 45.39 & 41.87 & 45.26 & 44.12 & 2.45 \\
\hline SMI & & Mi26 & & & Sab3k & \\
\hline \# analyses & $\mathrm{Pl}$ & $\mathrm{Cpx}$ & $\| \mathrm{m}$ & $\mathrm{PI}$ & $\mathrm{Cpx}$ & IIm \\
\hline $\mathrm{SiO}_{2}$ & 68.48 & 65.27 & 53.90 & 64.40 & 69.49 & 62.57 \\
\hline $\mathrm{TiO}_{2}$ & 0.16 & 0.28 & 2.31 & 1.36 & 0.33 & 2.66 \\
\hline $\mathrm{Cr}_{2} \mathrm{O}_{3}$ & na & na & 0.02 & na & na & na \\
\hline $\mathrm{Al}_{2} \mathrm{O}_{3}$ & 16.50 & 12.55 & 11.95 & 14.48 & 13.10 & 14.41 \\
\hline $\mathrm{FeO}$ tot & 1.44 & 5.64 & 17.66 & 6.60 & 3.85 & 6.93 \\
\hline $\mathrm{MnO}$ & 0.06 & 0.08 & 0.26 & 0.16 & 0.09 & 0.22 \\
\hline $\mathrm{MgO}$ & 0.21 & 0.84 & 2.81 & 0.77 & 0.07 & 0.99 \\
\hline $\mathrm{CaO}$ & 2.56 & 3.23 & 3.73 & 2.12 & 1.34 & 3.32 \\
\hline $\mathrm{Na}_{2} \mathrm{O}$ & 2.52 & 1.94 & 2.23 & 3.23 & 2.52 & 3.76 \\
\hline $\mathrm{K}_{2} \mathrm{O}$ & 4.13 & 4.87 & 4.26 & 3.94 & 4.99 & 4.23 \\
\hline $\mathrm{Cl}$ & 0.15 & 0.10 & 0.08 & 0.07 & 0.13 & 0.15 \\
\hline$\Sigma$ & 96.20 & 94.80 & 99.22 & 97.13 & 95.89 & 99.24 \\
\hline
\end{tabular}


Table 3 The result of the Raman spectroscopy. Tm - final melting temperature; Th - homogenization temperature. Mineral abbreviations follow Kretz (1983).* ${ }^{*}$ water' was detected at $1500^{\circ} \mathrm{C}$
sample

\begin{tabular}{|c|c|c|c|c|c|c|c|c|c|c|c|c|c|c|c|c|c|c|c|c|c|c|c|c|}
\hline sample & FIJWII & type & nostmin: & textural position & & $I m_{t}$ & & & In & & $\mathrm{CO}_{2}+2,+2$ & & & & & & & & & & & $72 O(\mathrm{mo}$ & & \\
\hline & & & & & $\min$ & $\max$ & $n$ & $\min$ & $\max$ & $n$ & $\min$ & $\max$ & $\min$ & $\max$ & $\min$ & $\max$ & $\min$ & $\max$ & $\min$ & $\max$ & $\min$ & $\max$ & $150^{\circ} \mathrm{C}$ & $n$ \\
\hline Sab38_vein & $\mathrm{Fl}$ & 1 & $\mathrm{Pl}$ & primary, vein, without SMI & nd & nd & & nd & nd & & 66.2 & 75.6 & 0 & 0.1 & 0.3 & 0.4 & 0.1 & 0.2 & 23.8 & 30.3 & 0 & 2.9 & na & 2 \\
\hline & $\mathrm{Fl}$ & $\|$ & $\mathrm{Pl}$ & primary, vein, between SMI & nd & nd & & & nd & & & & 0 & & & 0 & 0 & 0.28 & & 9.7 & 0 & & $b d$ & \\
\hline & SMI & $G$ & $\mathrm{Pl}$ & primary, vein & -60.2 & -59.6 & 2 & 8.7 & & 1 & 88 & 100 & 0 & 0 & 0 & 4.3 & 0 & 0 & 0 & 7.6 & 0 & 0 & bd & 11 \\
\hline & & $G$ & & & & & & & nd & & & 100 & 0 & & & 0.2 & & 0 & & 0 & & & & 7 \\
\hline Sab38_wall & $\mathrm{Fl}$ & III & $\mathrm{Pl}$ & primary, wall, without SMI & nd & nd & & nd & nd & & 86 & & 0 & 0 & 0 & & 0.3 & & 13.7 & & 0 & 0 & $\mathrm{bd}$ & 1 \\
\hline Mi26 & $\mathrm{Fl}$ & 1 & $\overline{\mathrm{Cpx}}$ & primary, without SMI & nd & nd & & nd & nd & & 98.7 & & 0 & 0 & 0.7 & & 0 & 0 & 0 & & 0.6 & & na & 1 \\
\hline & $\mathrm{Fl}$ & $\|$ & $\mathrm{Pl}$ & primary, between SMI & $\mathrm{nd}$ & nd & & nd & nd & & 83.5 & 100 & 0 & 0 & 0 & 6 & 0 & 0 & 0 & 10.5 & 0 & 0 & 6.1 & 2 \\
\hline & SMI & $G$ & $\mathrm{Pl}$ & primary & nd & nd & & nd & nd & & 79.8 & 100 & 0 & 0 & 0 & 3.2 & 0 & 0 & 0 & 17 & 0 & 0 & 0.7 & 5 \\
\hline & SMI & $G_{2}-c_{2}$ & $\operatorname{cox}$ & primary & nd & nd & & nd & nd & & 967 & 100 & 0 & 0 & 0 & 0.51 & 0 & 0 & 0 & 0 & 0 & 2.1 & 3.3 & 4 \\
\hline
\end{tabular}


Table 4 The 'water' content in ppm wt. \% for plagioclase and clinopyroxene host minerals, and the average 'water' content of the xenoliths using the modes of minerals. Mineral abbreviations after Kretz

\begin{tabular}{|c|c|c|c|c|c|c|c|c|c|c|c|c|c|c|c|c|}
\hline \multirow{2}{*}{ Sample } & \multicolumn{3}{|c|}{$P l(p p m$ wt. \%) } & \multirow{2}{*}{$n$} & \multicolumn{7}{|c|}{ inclusion-free grains } & \multicolumn{5}{|c|}{ Qtz (ppm wt. \%) } \\
\hline & $\min$ & $\max$ & average & & $\min$ & $\max$ & average & & $\min$ & $\max$ & average & $n$ & min & $\max$ & average & $n$ \\
\hline \multirow{2}{*}{$\begin{array}{l}\text { Mi26_wall rock } \\
\text { Mi26_melt pocket } \\
\text { Sab38_wall rock } \\
\text { Sab38_vein } \\
\end{array}$} & 0 & 240 & $120 \pm 36$ & 12 & 87 & 271 & $183 \pm 55$ & 10 & \multirow{2}{*}{189} & 193 & \multirow{2}{*}{ 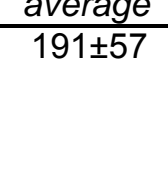 } & \multirow[t]{2}{*}{2} & & & & \\
\hline & $\begin{array}{l}7 \\
0\end{array}$ & $\begin{array}{l}59 \\
24\end{array}$ & $\begin{array}{c}33 \pm 10 \\
12 \pm 4\end{array}$ & $\begin{array}{l}8 \\
6\end{array}$ & $\begin{array}{l}29 \\
73\end{array}$ & $\begin{array}{l}200 \\
190\end{array}$ & $\begin{array}{l}112 \pm 33 \\
137 \pm 41\end{array}$ & $\begin{array}{l}11 \\
10\end{array}$ & & & & & 51 & & $55 \pm 17$ & 2 \\
\hline \multirow{3}{*}{$\begin{array}{l}\text { Mi26_wall rock } \\
\text { Mi26_melt pocket } \\
\text { Sab38_wall rock } \\
\text { Sab38_vein }\end{array}$} & & $P($ ppom $)$ & & $\begin{array}{c}\text { usior } \\
n\end{array}$ & $\begin{array}{l}\mathrm{ng}_{\mathrm{ma}} \\
\mathrm{man}\end{array}$ & spx (ppon & & $n$ & \multirow{3}{*}{\multicolumn{3}{|c|}{ 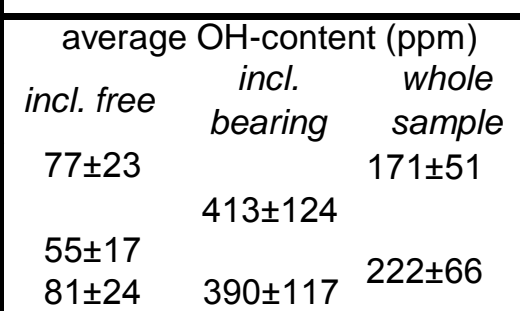 }} & & & & & \\
\hline & $\min$ & $\max$ & averaget & 11 & $\min$ & 227 & average $e^{*}$ & 11 & & & & & & & & \\
\hline & 19 & 684 & 600 & 4 & 155 & 182 & 180 & 2 & & & & & & & & \\
\hline
\end{tabular}

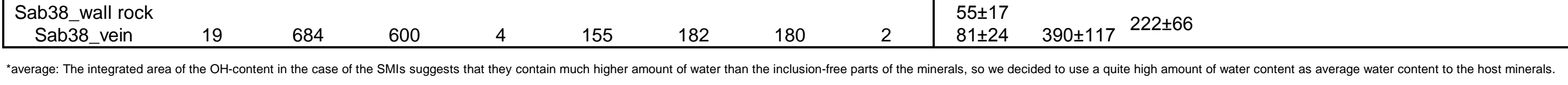

